\title{
Assessment of Nutrient Status in Athletes and the Need for Supplementation
}

\author{
D. Enette Larson-Meyer \\ University of Wyoming \\ Kathleen Woolf \\ NYU Steinhardt \\ Louise Burke \\ Australian Institute of Sport
}

\begin{abstract}
Nutrition assessment is a necessary first step in advising athletes on dietary strategies that include dietary supplementation, and in evaluating the effectiveness of supplementation regimens. Although dietary assessment is the cornerstone component of the nutrition assessment process, it should be performed within the context of a complete assessment that includes collection/ evaluation of anthropometric, biochemical, clinical, and environmental data. Collection of dietary intake data can be challenging, with the potential for significant error of validity and reliability, which include inherent errors of the collection methodology, coding of data by dietitians, estimation of nutrient composition using nutrient food tables and/or dietary software programs, and expression of data relative to reference standards including eating guidance systems, macronutrient guidelines for athletes, and recommended dietary allowances. Limitations in methodologies used to complete anthropometric assessment and biochemical analysis also exist, as reference norms for the athlete are not well established and practical and reliable biomarkers are not available for all nutrients. A clinical assessment collected from history information and the nutrition-focused physical exam may help identify overt nutrient deficiencies but may be unremarkable in the well-trained athlete. Assessment of potential food-drug interactions and environmental components further helps make appropriate dietary and supplement recommendations. Overall, the assessment process can help the athlete understand that supplement intake cannot make up for poor food choices and an inadequate diet, while a healthy diet helps ensure maximal benefit from supplementation. Establishment of reference norms specifically for well-trained athletes for the nutrition assessment process is a future research priority.
\end{abstract}

Keywords: body composition, clinical evaluation, dietary supplements, health care, nutrition

Athletes of all abilities-particularly at the elite level-are encouraged to follow sports nutrition strategies that optimize mental and physical performance and support good health (Maughan \& Shirreffs, 2011). These strategies include eating a well-chosen diet with sufficient energy to meet the macronutrient and micronutrient requirements of training and competition, achieving optimal body mass (BM) and composition, and adopting specific nutritional strategies before, during, and after training to optimize performance (Maughan \& Shirreffs, 2011; Thomas et al., 2016). The selection of nutrient-rich foods is also important for reducing risk of nutrient deficiencies that may impair both health and performance, particularly when energy intake is restricted to reduce body mass/fat mass. Although athletes benefit from the guidance of a sports dietitian on individual energy, nutrient, and fluid needs, or assistance with sport-specific nutrition strategies, advice on supplement use is also commonly desired. The use of

\footnotetext{
Larson-Meyer is with the Nutrition \& Exercise Laboratory, Department of Family and Consumer Sciences, University of Wyoming, Laramie, WY. Woolf is with the Department of Nutrition and Food Studies, NYU Steinhardt, New York, NY. Burke is with the Australian Institute of Sport, Bruce, Australia. Address author correspondence to D. Enette Larson-Meyer at enette@uwyo.edu.
}

dietary supplements, however, should not compensate for poor food choices and an inadequate diet, except as a short-term strategy when dietary changes are not possible (Maughan \& Shirreffs, 2011). Rather, a well-chosen diet underpins the benefits of evidence-based use of supplements, whether they are taken to maximize performance, delay fatigue, alter physique, or improve health. An athlete who has compromised iron status, for example, or who is not timing protein intake in relation to training is unlikely to achieve the full benefits of supplements geared at optimizing endurance or promoting muscle gain, respectively.

A nutrition assessment is the first step in advising athletes on dietary strategies or supplement use. Nutrition assessment is the "systematic method for obtaining, verifying and interpreting data needed to identify nutrition-related problems, their causes and their significance" (Academy of Nutrition and Dietetics, 2015). A complete assessment should ideally include dietary evaluation, anthropometry and body composition analysis, biochemical testing, nutrition-focused clinical examination, and patient history (Academy of Nutrition and Dietetics, 2015; Driskell \& Wolinsky, 2010). In the sport setting, nutrition assessment in relation to dietary supplement use should ensure the athlete (a) is consuming a well-chosen sports nutrition plan that is adequate in energy, 
macronutrients, and micronutrients; (b) is not at risk for health issues, including interactions with prescription or over-the-counter medications (Deal \& VanReken, 2017); and (c) would benefit from dietary supplements and is knowledgeable about the appropriate supplementation protocol. Failing to do so may compromise the effectiveness of the supplementation protocol and could lead to excess vitamin and mineral intakes and/or fooddrug interactions.

This paper summarizes the comprehensive assessment of an individual athlete's nutritional status, using the traditional "A-E" framework of Anthropometric, Biochemical, Clinical, Dietary, and Environmental assessment (Boosalis, 2010) to evaluate the need for dietary supplements, rather than its more common application to populations who are severely malnourished or burdened with chronic disease. The paper also highlights the assumptions and possible error in the collection of anthropometric, biochemical, and dietary data that must be considered in the assessment process, and the lack of reference norms specifically for the athlete.

\section{D: Dietary Assessment}

Although dietary assessment is toward the alphabetic end of the A-E assessment framework, this component is discussed first, rather than in alphabetical order, because it is the cornerstone of the nutrition assessment process (Lee \& Nieman, 2013), and a daily event for the sports dietitian (Burke, 2015). The dietary assessment is routinely used for evaluating what an athlete eats, either over a specific period or in a typical day. The outcomes may include quantification of total energy, macronutrient or micronutrient intake, and/or estimation of diet quality (e.g., adequacy of intake of certain foods, timing of intake around training/competition).

Dietary assessment methodologies are commonly classified as retrospective (recalling what was consumed) or prospective (measuring future intake). Retrospective methods include dietary recalls (typically the 24-hr recall), food frequency questionnaires (FFQ), and diet histories. Prospective methods encompass food records as well as direct observation (e.g., at a training table). Although the assessment method should match the purpose of the activity, in many cases it is determined by the available resources (e.g., time and staffing constraints, athlete burden, access to food models, portable food scales, dietary software programs, etc). A summary of the general advantages and limitations of common dietary assessment methods is provided in Table 1 and reviewed more extensively elsewhere (Bingham, 1991; Lee \& Nieman, 2013; Thompson \& Subar, 2008), including special commentary on athletes (Burke, 2015; Magkos \& Yannakoulia, 2003). Some brief additional comments on dietary assessment tools in relation to athletes and/or supplement issues are provided below.

\section{Retrospective Methods}

The 24-hr recall is the least frequently used assessment method in sports nutrition (Burke, 2015), but may be useful when evaluating timing of food or supplement intake in relation to exercise, gastrointestinal distress, or food allergy. FFQs are particularly helpful when assessing the status of nutrients with a limited number of rich dietary sources, such as antioxidants (Braakhuis et al., 2011), vitamin D (Halliday et al., 2011), calcium, and iodine. The FFQ methodology, however, strips away some valuable information, including the timing of food/beverage intake and the combinations of foods/beverages consumed in the same meal/snack (Burke, 2015). Although the diet history is one of the preferred methods for obtaining estimates of usual nutrient intake, the information/data collected is not easily quantifiable and may be more appropriate for qualitative assessment (Thompson \& Subar, 2008). Though all three recall methodologies are challenged by the athlete's ability to accurately describe typical portion sizes of foods/beverages consumed, tools such as food models, pictures of food, geometric shapes, and standard household measures and/or dishes can assist the athlete to better describe quantities consumed (Burke, 2015).

\section{Prospective Methods}

Completing food records is conceptually a straightforward task, however, it requires the athlete to be trained, literate, and compliant to the task. Methodological issues that influence the validity and reliability of data to unknown degrees include the number of days of recording and whether food portions are estimated or weighed. Although a larger number of days is likely to increase the probability of obtaining a "true" picture of usual intake, it also increases the likelihood of recording fatigue (i.e., the athlete grows tired of the task and becomes either less compliant or changes intake to simplify the process) (Trabulsi \& Schoeller, 2001). Most people are unaware that, due to daily variability in food intake, the number of recording days needed to truly represent an individual's mean intake for energy and various nutrients is highly variable and often longer than the 3-day to 14-day records typically kept. A study undertaken in healthy nonathletic participants, for example indicated that this may be as long as 21 days for protein to over 8 months for vitamin C (Table 2). Whether these findings hold in athletes who may have more variable intake due to their periodized training/nutrition cycles or less variable intake from often regimented eating practices is yet to be determined. The weighing of food versus estimation using household measurements is typically another trade-off between better accuracy versus greater effort/ lower compliance, but this may differ for athletes who are accustomed to intricate daily recording of metrics around training (Burke, 2015).

Like the 24-hr recall, food records tend to underestimate energy intake when compared to doubly-labeled water measurements of energy expenditure (Livingstone \& Black, 2003; Magkos \& Yannakoulia, 2003; Trabulsi \& Schoeller, 2001), and have additional errors of validity if the athlete changes behavior in the process. Unfortunately, the magnitude of the under-reporting is difficult to discern and may have nonsystematic errors that vary among individuals (Trabulsi \& Schoeller, 2001) and by sport (Magkos \& Yannakoulia, 2003). Among the general population, it is estimated $\sim 30 \%$ of individuals underestimate food intake, with the average magnitude of underreporting being 15\% (Poslusna et al., 2009). Among athletes, underreporting has been estimated to account for $10-45 \%$ of total energy expenditure (Magkos \& Yannakoulia, 2003). The physical and psychological factors that predict underreporting among athletes and the general public include body dissatisfaction, weight consciousness, social desirability, and a relatively high daily energy expenditure (Livingstone \& Black, 2003; Magkos \& Yannakoulia, 2003; Trabulsi \& Schoeller, 2001). Additionally, under-reporting may be selective to certain foods and nutrients. For example, fiber is commonly over-reported, and sodium, potassium, and calcium intakes are commonly under-reported (Johansson et al., 1998). These observations unfortunately prevent the use of systematic adjustment factors and highlight the potential inaccuracies of estimates of energy and nutrient intakes in athletes. 
Table 1 Advantages, Disadvantages, and Potential Errors for Commonly-Used Methods for Dietary Assessment

\begin{tabular}{|c|c|c|}
\hline Method & Advantages & Disadvantages and Potential Errors \\
\hline $\begin{array}{l}\text { Diet recall (24-hr recall): Interviewer } \\
\text { helps athlete recall consumption of food, } \\
\text { beverages, and condiments over the } \\
\text { previous day or } 24 \mathrm{hr} \text { (or longer), and } \\
\text { assists athletes in determining portion sizes } \\
\text { for items consumed }{ }^{\mathrm{a}, \mathrm{b}} \text {. Interviewer } \\
\text { typically begins either with first thing } \\
\text { consumed upon waking the previous day or } \\
\text { at the point exactly } 24 \text { hr prior and working } \\
\text { forward. Asking about activities during } \\
\text { the day helps recall intake. }\end{array}$ & $\begin{array}{l}\text { - Provides reasonably accurate data about } \\
\text { the preceding day’s intake } \\
\text { - Does not alter usual intake } \\
\text { - Relatively quick }(\sim 15-30 \mathrm{~min}) \text { and easy } \\
\text { to administer } \\
\text { - Relatively inexpensive } \\
\text { - Low respondent burden } \\
\text { - More objective than diet history }\end{array}$ & $\begin{array}{l}\text { - A single 24-hr recall does not reflect } \\
\text { usual intake } \mathrm{a}^{\mathrm{a}-\mathrm{c}} \\
\text { - Relies on athlete's memory/ability to } \\
\text { recall } \\
\text { - Tendency for underreporting of energy } \\
\text { compared with direct measurement by } \\
\text { doubly-labeled water }{ }^{\mathrm{c}, \mathrm{i}} \\
\text { - Omission of dressings, sauces, beverages } \\
\text { and snacks common; contributes to } \\
\text { underreporting } \\
\text { - Food coding and analysis using nutrient } \\
\text { analysis software is time-consuming and } \\
\text { introduces additional error }\end{array}$ \\
\hline $\begin{array}{l}\text { Multiple-pass 24-hr recall: Interviewer } \\
\text { and respondent review previous day } \\
\text { several times (i.e., passes). In the } \\
\text { NHANES-version, }{ }^{\mathrm{a}, \mathrm{d}, \mathrm{e}} \text { a quick list of foods } \\
\text { is compiled on first pass, followed by } \\
\text { information about time and occasion foods }\end{array}$ & $\begin{array}{l}\text { - Systematic procedure focuses on helping } \\
\text { athletes remember all foods consumed, } \\
\text { including dressings, sauces and beverages } \\
\text { - Limits underreporting. In nonathletes, the } \\
\text { multipass method assessed mean energy, } \\
\text { carbohydrate, protein, and fat within }\end{array}$ & $\begin{array}{l}\text { - More time-consuming (30-45 min })^{\mathrm{a}} \text { than } \\
\text { the above } \\
\text { - Adequate training of interviewer } \\
\text { needed } \\
\text { - Food coding and nutrient analysis (as } \\
\text { above) introduce additional error }\end{array}$ \\
\hline
\end{tabular}

were consumed and queries about

frequently-forgotten foods (second and third passes). Detailed description/ quantification of foods on the quick list is than obtained (fourth pass) followed by a review of data collected, with interviewer probing for additional foods (fifth pass).

Multiple 24-hr recalls: Repeated multiple 24-hr recalls collected using various protocols. NHANES obtains the first multiple-pass recall in person and a second one by telephone 3-10 days later.

Food frequency questionnaire: Process asks athletes to identify how often they eat a specific list of individual foods/beverages (or food categories) with frequency typically recorded in times per day, week, month, or year. Qualitative FFQs ask respondents to describe the size of usual servings relative to typical servings; semi-qualitative states standard servings and nonqualitative does not address portion sizes $^{\mathrm{a}, \mathrm{b}}$. FFQs can be implemented by a trained interviewer or self-administered by the athlete, using paper or electronic questionnaire. carbohydrate, protein, and fat within $7-10 \%$ of actual observed intake ${ }^{\mathrm{d}, \mathrm{e}}$

- Multiple recalls in individual athlete spaced over various seasons may provide a reasonable estimate of usual nutrient intake $\mathrm{e}^{\mathrm{a}, \mathrm{b}, \mathrm{i}}$

- May be more representative of usual intake than a few days of collected data

- Cost-effective for analysis of large groups of athletes

- Can be self-administered via paper or electronically; electronic questionnaires save time and resources

- Modest demand on respondent

- Useful for gaining insight into usual intake and pattern of meals, snacks, intake around training sessions/events, and dietary supplement use ${ }^{\mathrm{f}}$

- Can detect seasonal intake differences

- Often correlates well with biochemical measures

- Less dependent on memory. Most people can recall what they typically eat better than exactly what they ate during a specific period of time
- Unlikely to measure intake of infrequently-consumed foods

- Food coding and nutrient analysis (as above) introduce additional error

- Relies on memory/ability to recall

- May not represent usual foods or portion sizes consumed by athletes ${ }^{\mathrm{f}}$

- Intake data compromised when multiple foods are grouped within single listings

- Tendency for progression to mean (overestimates intake in low-energy consumers and underestimates intake in higher intake consumers), but underestimation of energy also reported $^{\mathrm{c}, \mathrm{i}}$

- A FFQ developed in male athletes predicted intake of group but not individuals $^{\mathrm{g}}$

- Does not collect information on meal or eating patterns ${ }^{\mathrm{f}}$

- Interview is lengthy (up to an hour); highly-trained interviewer required

- Difficult to code for analysis, given that "typical" intake may include several examples of meals

- Errors in food coding and nutrient analysis (as noted above)

- Tendency to overestimate nutrient intake $^{\mathrm{a}, \mathrm{b}}$ but underestimation also observed $^{\mathrm{c}}$

- Requires cooperative respondents with ability to recall usual diet and habits ${ }^{\mathrm{b}}$ 
Table 1 (continued)

\begin{tabular}{|c|c|c|}
\hline Method & Advantages & Disadvantages and Potential Errors \\
\hline $\begin{array}{l}\text { Food records (food diaries): Athlete } \\
\text { records all food and beverages consumed } \\
\text { for the desired period with details provided } \\
\text { on specific brands, cooking methods, etc. } \\
\text { Food/beverage consumption quantified } \\
\text { using standard household measures or by } \\
\text { weighing all consumed items on a food } \\
\text { scale, providing information from a food } \\
\text { label. }\end{array}$ & $\begin{array}{l}\text { - Not dependent on memory } \\
\text { - Can provide detailed intake data and } \\
\text { quantitative information about eating } \\
\text { habits, particularly with weighed records } \\
\text { - Intake of multiple days more } \\
\text { representative of usual intake } \\
\text { - Reasonably valid depending on physical } \\
\text { and psychological profiles of athlete }\end{array}$ & $\begin{array}{l}\text { - High subject burden } \\
\text { - Results depend on athlete's cooperation, } \\
\text { attention to detail, and ability/desire to } \\
\text { record foods at the time of consumption } \\
\text { - Act of recording may alter diet toward } \\
\text { progression of perceived better eating } \\
\text { patterns } \\
\text { - Weighed food record more accurate than } \\
\text { estimated ones in nonathletes; this may } \\
\text { be different in athletes. Weighing of } \\
\text { individual food items at time of } \\
\text { consumption may not be convenient for } \\
\text { athletes consuming food before, during } \\
\text { or after practice or "on the move"b } \\
\text { - Under-recording error (unintentional or } \\
\text { intentional) is high and may account for } \\
\text { 10-45\% of total energy expenditure } \\
\text { when compared to doubly labeled } \\
\text { waterh; magnitude of error of under- } \\
\text { recording higher with higher energy } \\
\text { intakes } \\
\text { - Under-recording error, however, is } \\
\text { highly variable; some athletes } \\
\text { underreport while others may overreport. } \\
\text { This precludes general adjustments of } \\
\text { intake. c, } \\
\text { - Food coding and analysis using nutrient } \\
\text { analysis software extremely time } \\
\text { consuming }\end{array}$ \\
\hline
\end{tabular}

Sources: ${ }^{\mathrm{a}}$ Lee \& Nieman, 2013; ${ }^{\mathrm{b}}$ Thompson \& Subar, 2008; ${ }^{\mathrm{c}}$ Trabulsi \& Schoeller, 2001; ${ }^{\mathrm{d}}$ Conway et al., 2003; ${ }^{\mathrm{e}}$ Conway et al., 2004; ${ }^{\mathrm{f}}$ Burke, 2015; ${ }^{\mathrm{g}}$ Fogelholm \& Lahti-Koski, 1991; ${ }^{\text {h}}$ Poslusna et al., 2009; ${ }^{\text {i } F r e e d m a n ~ e t ~ a l ., ~} 2014$.

\section{Nutrient Analysis}

Regardless of the method of collection of dietary intake information, the assessment of nutrient adequacy is undertaken by estimating energy and nutrient content from food composition tables or databases, which provide information on the average composition of particular foodstuffs. Errors in the "coding" or matching of the described foods and beverages to the closest item in the database, as well as errors in the food composition values, introduce additional issues around reliability and validity (Adelman et al., 1983; Braakhuis et al., 2003; Guilland et al., 1993; United States Department of Agriculture [USDA] Agricultural Research Service, 2017). These errors include systematic bias with regard to the types of foods missing from the database (which may include specialty items, brands of sports foods), misreading of the food records, or error in data entry. Braakhuis and colleagues (2003) highlighted the potential variability provided by coding decisions by examining daily estimates of energy and nutrient intakes of elite athletes from the same food diaries processed by different sports dietitians. Although the coding-based variability was less than the athlete's day-to-day variability for a single day's record, it was similar to the variability in an average 7-day record. The study also highlighted substantial differences in the variability of nutrients with nearly a three-fold higher day-to-day variability observed for vitamin $\mathrm{C}$, vitamin $\mathrm{A}$, and cholesterol intakes compared to energy, carbohydrate, and magnesium intakes.

Errors in food composition values may result from both true random variability in the nutrient content of food or from systematic errors (Gibson, 2005). Such errors depend on the food/ beverage and the nutrient(s) of interest, and can result in either under- or overestimation of intake in an unknown direction and magnitude. Errors associated with the direct chemical analysis of foods depend on numerous factors, including sampling protocol, sampling size, and the pooling of similar commercially-available foods into a single average for the food table. Values obtained from different sources (e.g., government laboratories, the food industry, published or unpublished research) may use different analytical methods with differing acceptable error. Additionally, the nutrient content of foods may vary with growing location and conditions, season, stage of maturity, cooking procedure, and storage time prior to consumption. For example, the vitamin $\mathrm{C}$ content of raw broccoli may differ to the $91 \mathrm{mg} / 100 \mathrm{~g}$ listed in the USDA National Nutrient Database (USDA Agrigulture Research Service, 2017) depending on the variety, the season, and whether eaten freshly picked (Wunderlich et al., 2008) or over- or undercooked. For trace minerals, such as iodine, selenium, and zinc, the mineral content of the food is dependent on local agronomy practices and the mineral content of the soil, which cannot be accounted for in databases.

\section{Interpretation of Outcomes}

Depending on the assessment goals, a variety of reference standards may be used to qualitatively or quantitatively assess the athlete's diet (Lee \& Nieman, 2013). Qualitative assessment can compare the athlete's intake to the food guidance models or dietary guidelines of the athlete's home country or to general healthy eating guidelines for athletes. Examples of food guidance systems include the USDA's MyPlate, the United Kingdom's Eatwell Plate, Canada's Food Rainbow, Japan's Spinning Top, China's Pagoda, and France's Staircase for Healthy Eating (Keats \& Wiggins, 2014; 
Table 2 Number of Days of Diet Records Required to Estimate True Average Intake for Individuals

\begin{tabular}{lcc}
\hline Nutrient & Men & Women \\
\hline & 27 & (Days) \\
Energy & 23 & 35 \\
Protein & 37 & 23 \\
Carbohydrate & 82 & 41 \\
Fiber (crude) & 57 & 86 \\
Fat & 71 & 71 \\
Saturated fat & 68 & 87 \\
Oleic acid & 145 & 85 \\
Linoleic acid & 139 & 166 \\
Cholesterol & 390 & 200 \\
Vitamin A & 138 & 474 \\
Thiamine & 57 & 198 \\
Riboflavin & 53 & 90 \\
Riboflavin & 249 & 78 \\
Vitamin C & 74 & 222 \\
Calcium & 68 & 88 \\
Iron & 32 & 66 \\
Phosphorus & 34 & 41 \\
Potassium & 58 & 48 \\
Sodium & 82 & 73 \\
Fiber & & 86 \\
\hline Note.Estinas & & \\
\hline
\end{tabular}

Note. Estimates with intake data from the 1-year dietary intake study by the USDA's Beltsville Human Nutrition Research Center in nonathletic men and women. Days required to estimate true average intake for groups of individuals is less (range = 3 days for energy and 33 days for vitamin C; [Basiotis et al., 1987]). Similar data have not been collected in athletes and may be different in athletic populations due to periodized training/nutrition cycles and/or regimented eating practice. Data illustrate, however, that a significant number of days of diet records (i.e., greater than 7 days) are likely required to obtain a true representation of the athlete's intake and are important for understanding the limitation of this methodology.

Yadrick, 2017). Although these models were not originally meant to serve as standards for nutrient adequacy, they are useful for comparing the foods and portions consumed by the individual athlete with those recommended by the guidance system (Lee \& Nieman, 2013). Dietary guidelines for the public (e.g., the Dietary Guidelines for Americans presented by the U.S. Department of Health and Human Services and U.S. Department of Agriculture, 2015) or specific guidelines for athletes, such as recommendations within the International Olympic Committee (IOC) Consensus on Nutrition for Sport (Maughan \& Shirreffs, 2011) or the Joint Position Statement of the American College of Sports Medicine and others (Thomas et al., 2016), can be used in a similar manner. Comparison standards for a more quantitative assessment include the specific recommendations for carbohydrate and protein intakes of athletes (Burke et al., 2011; Phillips \& Van Loon, 2011; Thomas et al., 2016) and the dietary reference intakes (DRIs) (Lee \& Nieman, 2013) of the athlete's country or the World Health Organization. The DRIs for micronutrients in the United States and Canada encompass the estimated average requirement ([EAR] a guideline estimated to meet the requirement of half of the healthy individuals in a population), the recommended dietary allowance ([RDA] a value believed to meet the needs of $97.5 \%$ of a healthy population), the adequate intake ([AI] a recommendation for nutrients lacking sufficient evidence to establish an RDA) and the tolerable upper intake level ([UL] the highest intake level that can be tolerated without ill effects) (Otten et al., 2006). It should be noted that the purpose of the DRIs is to assess the adequacy of intake of populations rather than individuals (Food and Nutrition Board, 2000) and that comparing a single day's intake with the RDA is of little use for assessing an athlete's micronutrient status given the number of days of intake data needed to estimate "usual" intake (Food and Nutrition Board, 2000). Nevertheless, the RDA is the best reference for evaluation of nutrient sufficiency and deficiency. An athlete's intake data averaged over a 5-day to 8-day period are a reasonable reference point, and should not fall below the EAR and/or AI (indicating a high probability intake in inadequate) or above the UL (indicating possible risk for adverse effects from excessive intake).

\section{A: Anthropometrics}

Anthropometric assessment of body size and body composition is especially important in weight class, gravitational, and aesthetic sports, where it may influence competition qualification, performance, or adjudication (Ackland et al., 2012). Anthropometrics, defined as physical measures, commonly include measurement of height, weight, body circumferences (e.g., waist, hip, mid-thigh, calf, bicep), and subcutaneous ("skinfold") fat thickness. All measurements, including fundamental metrics such as height and BM, should be performed using standardized procedures and appropriate, properly-calibrated equipment to enhance validity and reliability (Table 3). Height and BM from self-report (or sport rosters) are not appropriate for assessment purposes as they tend to overestimate height and misreport BM in nonathletes (Popa et al., 2017). Concerns around the suitability of athlete-specific norms or "ideal" standards for anthropometric measurements have increased the importance of serial measures performed in the athlete. These measures can be used to monitor changes in body size and composition due to growth or the outcomes of training and/or dietary manipulation and should be performed by the same technician using the same equipment.

Although there are a variety of ways to measure body size and composition in athletes, the IOC ad hoc research working group on body composition, health, and performance (Ackland et al., 2012) recommends the procedures established by the International Society for the Advancement of Kinanthropometry (ISAK) (Stewart et al., 2011) or published in the Anthropometric Standardization Reference Manual (Lohman, 1988). ISAK has developed specific protocols for standardized anthropometric profiling, including identification of measurement sites, measurement techniques, and equipment. ISAK also supports training and certification of nutrition/exercise professionals and promotes the collection of intertester error and standards for intratester error of repeated measures. Such standardization is likely to reduce intratester and intertester measurement errors and enhance the comparison of serial measurements in individuals or between group profiles. Conversion of sum of skinfolds to estimates of body fat percent using regression equations should be done with caution because it introduces additional errors of assumption and validity (Table 3). Caution must also be taken when performing these measurements in athletes with body image concerns or who are uncomfortable with the process or results of physique assessment.

While other more "technical" methods of monitoring body composition are available, these techniques may not always be practical or affordable and may introduce some limitations in their application to athletic populations. For example, plethysmography equipment (i.e., the BODPOD) is expensive; furthermore, 
Table 3 Common Laboratory and Field Methods Used for Body Composition Assessment

\begin{tabular}{ll}
\hline Methodology & \\
\hline Anthropometry: & Measures body segment girths to \\
SEE $>3 \%$ & estimate body fat; ISAK \\
& recommended sites: arm (relaxed and \\
& flexed), waist and gluteal (hip) girths, \\
& and humerus and femur breadths ${ }^{\mathrm{a}}$
\end{tabular}

Bioelectrical impedance analysis: $\mathrm{SEE}=3.5 \%^{1}{ }_{\text {den }}$

Densitometry

Hydrodensitometry: $\mathrm{SEE}=2$ to $2.5 \%{ }^{\mathrm{d}}$

Plethysmography (BOD POD):

$\mathrm{SEE}=1.8 \%^{\mathrm{d}}$

estimate body volume; body density determined from body mass and

\section{Advantages}

- Convenient, inexpensive; can be done on large groups of athletes in the field and humerus and femur breadths

Measures resistance to alternating electrical current to predict total body water, with assumption that fat-free tissue conducts the current, whereas fat impedes it; fat-free mass and equations that consider height, BM, sex, and often physical activity level

- Minimal subject involvement during testing

- Minimal technical skill needed by technician

- No ionizing radiation

- Rapid data acquisition

- Apparent sophistication

- See information below for hydrodensitometry and plethysmography

Determines whole-body density (mass/unit volume) from estimates of body volume in water (hydrodensitometry) or by air displacement plethysmography; body composition estimated from body density assuming constant density of fat $=0.90 \mathrm{~g} / \mathrm{cm}^{3}$ and fat-free mass $=1.10 \mathrm{~g} / \mathrm{cm}^{3}$

Determines body volume by water submersion (i.e., underwater weighing [UWW]) in a specific tank using Archimedes' principle
- Previously considered the "Gold Standard"

- Large body of data collected in athletes that can be used as reference $\%$ body fat estimated from regression

\section{Limitations}

- Variability in frame size/ muscularity can induce variability

- Use of skeletal breadths induces additional error

- Limited accuracy ${ }^{\mathrm{b}}$

- Sensitive to fluid shifts and hydration status; dehydration overestimates of $\%$ body fat

- To ensure the most accurate results, athletes should not exercise for $\geq 12 \mathrm{hr}$ before testing, avoid alcohol, and drink plenty of water ${ }^{c}$

- Not recommended for assessing body composition changes over time ${ }^{\mathrm{d}}$

- Assumption that the density of fat-free tissue (including muscle and bone $)=1.10 \mathrm{~g} / \mathrm{cm}^{3}$ may not be valid for athletes of different sports and ethnicities, and may change with training and aging - this can result in significant errors in prediction of $\%$ body fat

- Estimates of lung volume required

- Subject to above errors of densitometry

- Time consuming

- Considerable technician expertise required

- Requires estimation of residual lung volume (while in water) and other entrapped air spaces such as intestinal gas

- Results influenced by athletes' comfort and cooperation in water

- Not supported in strength-trained athletes, those with low bone density, ${ }^{b}$ and athletes of certain ethnicities

- Subject to above errors of densitometry volume; body composition estimated from body density typically using Siri equation; comparable to UWW
- Quicker and easier on subject than UWW

- Less subject involvement than UWW

- May be more reliable and valid than UWW for some groups of athletes ${ }^{\mathrm{e}}$
- BODPOD must be kept in separate room with closely-regulated temperature and humidity

- Athlete must wear swimwear and swim cap

- Moisture on skin, body hair, clothing worn, ${ }^{\mathrm{f}}$ and type of swim cap ${ }^{\mathrm{g}}$ can induce large errors and must be consistent with repeated measurements

- Compared to UWW, may underestimate $\%$ body fat in some group of athletes and overestimate $\%$ body fat in others ${ }^{b}$

- Estimate of thoracic gas volume can cause additional errors 
Table 3 (continued)

\begin{tabular}{ll}
\hline Methodology & \\
\hline $\begin{array}{l}\text { Dual energy x-ray } \\
\text { absorptiometry }\end{array}$ & $\begin{array}{l}\text { Passes filtered, x-ray beams at two } \\
\text { different photon energies through }\end{array}$ \\
(DXA): & body; allows differentiation of bone, \\
fEE $=2-3 \%_{\mathrm{mc}}$ h & $\begin{array}{l}\text { fat, and fat-free mass because each } \\
\text { tissue differentiates photons } \\
\text { differently }\end{array}$
\end{tabular}

\section{Advantages}

- Fast (5-15 min depending on model and size of athlete)

- Good precision validation against porcine models ${ }^{\mathrm{b}}$

- Provides information about bone and lean tissue, not just fat-free mass

- Provides regional body composition information

- Minimal subject involvement

- Minimally affected by hydration (compared to other methods) $^{\mathrm{a}}$

- Nonintrusive
Skinfolds (sum), general and ISAK: $\mathrm{SEE}=\mathrm{N} \backslash \mathrm{A}$

Skinfolds used to predict body fat percentage
Measures subcutaneous fat folds at specific body sites; typically two to three measurements obtained on the right side of the body; ISAK procedures specify the triceps, biceps, subscapular, iliac crest, supraspinale, abdominal, front thigh, and medial calf measures be taken using Harpenden or Inovare calipers using a precise protocol ${ }^{\mathrm{a}}$

Sum of skinfolds used to estimate body fat percentage using one of many regression equations; care should be taken to select the most appropriate regression equation that should be specific for sex, age, sport, and caliper used, if possible; best validated equations include JacksonPollock in male and female athletes (against UWW) ${ }^{\mathrm{k}, \mathrm{l}}$ and the Lohman equation in male collegiate athletes ${ }^{\mathrm{m}}$; attention should be paid to selection of valid equation
- Low cost, convenient

- Reliable when done by trained technician

- Results can be compared with standards by sport

- Individual sites or sum of sites can be monitored over time

- Legitimate for test-retest on individuals

- Estimating body fat percent from sum of skinfolds has application in some individuals and groups

- Accurate results can be obtained using population-specific formulas for sex, age, ethnicity and sport

\section{Limitations}

- Use caution for repeated DXAs due to cumulative radiation $(0.5 \mu \mathrm{Sv})$ (no more than 4 scans/year recommended $^{\mathrm{b}}$ )

- Calibration algorithms are unpublished and differ between manufacturers ${ }^{\mathrm{h}}$; not developed on athletes

- Limited ability to detect small body composition changes over time ${ }^{\mathrm{b}}$

- Greater errors among athletes who are lean or excessively small or large ${ }^{b}$

- Limited scan bed size, thus taller (>192 cm) and larger athletes may not fit on scanner

- Food, beverage, and dietary supplement (i.e., calcium) consumption can influence results

- Standardized protocol should be used to increase reliability and when monitoring body composition changes over time; ideally, athletes should be euhydrated ${ }^{i}$, fasted, measured after voiding and defecating and having not exercised that day ${ }^{\mathrm{j}}$; positioning and clothing also standardized ${ }^{\mathrm{i}}$

- Samples subcutaneous fat only

- Can be intrusive for some athletes

- Some sites difficult to measure

- Standardization of measurement sites and techniques essential; varying skinfold site by $1 \mathrm{~cm}$ produces significantly different results in same participant $^{\mathrm{b}}$

- Different calipers may yield different results

- Numerous equations available using different skinfold sites which can cause confusion

- Conversion to \% body fat induces additional error due to assumptions which include that (a) thickness of skin is constant and negligible, (b) the skinfold has constant compressibility, (c) body fat is normally distributed, and (d) the proportion of internal to external fat is constant; most equations based on total body density measured by UWW

- Equations are population-specific and need to be cross validated for the group in question; methods not supported in those with obesity 
Table 3 (continued)

\begin{tabular}{|c|c|c|c|}
\hline Methodology & & Advantages & Limitations \\
\hline $\begin{array}{l}\text { Hand-held ultrasound } \\
\text { (to measure skinfold } \\
\text { thickness) }\end{array}$ & $\begin{array}{l}\text { Ultrasound technology allows } \\
\text { measurement of uncompressed } \\
\text { subcutaneous adipose tissue } \\
\text { thickness }{ }^{\text {n,o }} \text { using hand-held } \\
\text { device }\end{array}$ & $\begin{array}{l}\text { - Good accuracy }(0.1-0.5 \mathrm{~mm})^{\mathrm{n}, \mathrm{o}} \text { of } \\
\text { measurement of skinfold thickness but } \\
\text { dependent on probe frequency and site } \\
\text { - Appropriate for field testing } \\
\text { - May be more accurate than calipers } \\
\text { because skin does not need to be } \\
\text { compressed } \\
\text { - Excellent interrater reliability in } \\
\text { athletes }{ }^{\mathrm{p}, \mathrm{q}}\end{array}$ & $\begin{array}{l}\text { - Subcutaneous adipose tissue } \\
\text { thickness limited by plasticity of fat } \\
\text { and furrowed tissue borders } \\
\text { - Technique and equipment may still } \\
\text { be considered preliminary; both } \\
\text { A-mode and B-mode equipment is } \\
\text { being tested } \\
\text { - Equipment more expensive than } \\
\text { calipers } \\
\text { - Databases and norms in athletes are in } \\
\text { development } \\
\text { - One study suggested poor validity in } \\
\text { female athletes }\end{array}$ \\
\hline
\end{tabular}

Abbreviations: BM = body mass; ISAK = International Society for the Advancement of Kinanthropometry; SEE= standard error of estimate.

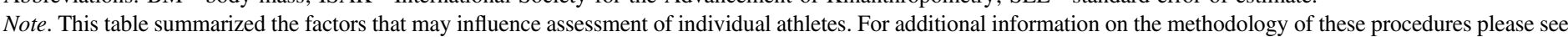

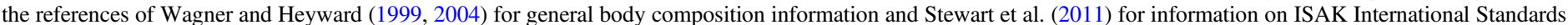
for Anthropometric Assessment.

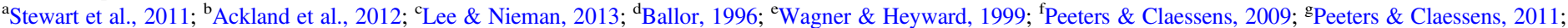

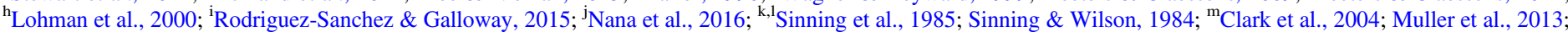
${ }^{\mathrm{n}, \mathrm{o}}$ Muller et al., 2013, 2016; ${ }^{\mathrm{p}}$ Wagner et al., 2016; ${ }^{\mathrm{q}}$ Kopinski et al., 2015

cross-validation studies in some athletic groups indicate it is no better than anthropometry for accurate and reliable assessment of body composition (Bentzur et al., 2008; Moon et al., 2008). Dualenergy $\mathrm{x}$-ray absorptiometry (DXA) requires an expensive scanner and trained personnel, but offers the advantage of measuring lean mass and bone mineral density as well as fat mass. Techniques such as handheld ultrasound devices to measure skinfold thickness and estimate body composition are becoming more widely available but are still considered emerging techniques that deserve further research. As outlined in Table 3, commonly-used body composition analysis techniques (Meyer et al., 2013) have inherent limitations that include methodological assumptions and measurement errors (Gibson, 2005; Wagner \& Heyward, 1999). Furthermore, most techniques have not been truly validated with cadaver analysis (for obvious reasons) but are cross-validated against underwater weighing (which has its own set of methodological errors). Cross validation against the more preferred multiple compartment model or medical imaging techniques (magnetic resonance imaging or computed tomography) have rarely been done. The limitations and potential measurement error of a selected technique are particularly important when performing serial measures to monitor changes induced by training, diet, or supplement use. The series of studies performed by Peeters and Claessens (2009, 2011) and Nana and colleagues (2012a, 2012b, 2013) using the DXA and BODPOD, respectively, illustrate how changes in clothing, hydration status, and meal consumption can impact repeated measures (Table 3) and support the need for protocol standardization (Nana et al., 2016).

\section{B: Biochemical}

Biochemical tests, also referred to as biomarkers, provide an objective and quantitative assessment of an athlete's current nutrition status or recent nutrient intake, and are especially useful to validate other assessment components such as dietary assessment (Lee \& Nieman, 2013). Biomarkers help determine what is happening internally, often detecting nutrient deficiency long before clinical signs and symptoms appear. Biochemical tests are grouped into two categories: static tests and functional tests (Lee \& Nieman,
2013). Static biochemical tests measure the concentration of a nutrient or its metabolites in biological fluids (Gibson, 2005; Lee \& Nieman, 2013); whole blood, serum, and plasma are the most frequently sampled tissues, but specific types of white blood cells, urine, saliva, and hair are also used. Serum and plasma concentrations of nutrients tend to reflect recent dietary intake or acute status unless the nutrient is homeostatically regulated (e.g., calcium or sodium) or buffered by extravascular sources (e.g., albumin and zinc). The nutrient content of erythrocytes, on the other hand, reflects longer-term nutrient status because their lifespan is $\sim 120$ days. Other biological fluids, including urine, can be useful when there is a consistent relationship between nutrient intake/status and excretion. Hair may prove useful for assessment of the status of specific trace minerals (Wojciak et al., 2004), including zinc (Lee \& Nieman, 2013), but this analysis is not yet common practice and can be confused with "nutrient hair analysis" of more dubious validity.

Functional tests of nutritional status, in contrast, are based on the ultimate outcome of the nutrient deficiency, which include failure of the metabolic pathways or physiological processes that rely on the nutrient in question. For example, they may measure the activity of an enzyme that requires the specific nutrient as a coenzyme (erythrocyte transketolase [thiamine], erythrocyte glutathione reductase [riboflavin]) or the concentration of a metabolic product that arises from reduced activity of a nutrient-dependent enzyme (methylmalonic acid [vitamin B12]) (Food and Nutrition Board of the Institute of Medicine, 1998; Gibson, 2005). Functional tests also include physiological and behavior outcomes (e.g., dark adaptation [vitamin A], taste acuity [zinc]) (Gibson, 2005). Some functional tests are nonspecific, meaning they indicate compromised nutritional status but do not pinpoint the specific nutrient deficiency (Lee \& Nieman, 2013). For example, plasma homocysteine is a sensitive indicator of folate status but may also be influenced by vitamin B6 and vitamin B12 status (Food and Nutrition Board of the Institute of Medicine, 1998).

In research, biochemical tests are used to evaluate the validity of dietary intake methods to help evaluate whether an athlete is under- or over-reporting food intake or is compliant with specific nutrition or supplement intervention. For example, protein intake assessed from a FFQ can be compared with 24-hr urinary nitrogen 
excretion, and reported/recorded sodium or potassium intake with 24-hr urinary sodium or potassium excretion (Lee \& Nieman, 2013), respectively. Compliance with calcium supplementation can be tested by measuring urinary calcium in the first-morning void (Weaver, 1990).

Although biochemical tests are a valuable adjunct in the assessment process, limitations of their use, especially in relation to their interaction with exercise or practicality of use in sports settings, must be considered. Table 4 summarizes the best or most commonly used biomarkers for key nutrients, their dietary sources, and associated manifestations of deficiency. It is important to recognize, however, that reference ranges or cut-off points for nutrient adequacy or deficiency, established in the general population, may not be appropriate norms for the well-trained athlete. Additional information is presented in Table 5 on biochemical markers of iron deficiency, since it is the micronutrient most at risk of suboptimal status in athletic populations. It is also important to note that some biochemical markers of iron status are altered by

Table 4 Biomarkers for Nutritional Assessment of Protein, Fluid, Vitamins, and Minerals: Reference Ranges, Dietary Sources, and Common Physical Manifestations

\begin{tabular}{|c|c|c|c|c|c|}
\hline Nutrient & $\begin{array}{l}\text { Dietary } \\
\text { Sources }^{a}\end{array}$ & $\begin{array}{l}\text { Biochemical Marker } \\
\text { of Status }\end{array}$ & Reference & $\begin{array}{l}\text { Physical } \\
\text { Manifestation }\end{array}$ & $\begin{array}{l}\text { Limitations and } \\
\text { Precautions }\end{array}$ \\
\hline Protein & $\begin{array}{l}\text { All meats, eggs, } \\
\text { milk, cheese, } \\
\text { legumes, select } \\
\text { vegetables and } \\
\text { grains }\end{array}$ & $\begin{array}{l}\text { Most common } \\
\text { measures: serum } \\
\text { albumin, transthyretin } \\
\text { ([TTHY], prealbumin), } \\
\text { transferrin (TF), retinol } \\
\text { binding protein (RBP) }\end{array}$ & $\begin{array}{l}\text { Reference range: } \\
\text { Albumin } 3.4-4.8 \mathrm{~g} / \mathrm{dL} \\
\text { TTHY } 10-40 \mathrm{mg} / \mathrm{dl} \\
\text { For RBP and TF, } \\
\text { reference ranges } \\
\text { determined by specific } \\
\text { laboratory. }\end{array}$ & $\begin{array}{l}\text { Weight loss, muscle } \\
\text { wasting, loss of } \\
\text { subcutaneous fat, } \\
\text { diminished functional } \\
\text { status (muscle weakness); } \\
\text { fluid accumulation in } \\
\text { tissues often present }^{b}\end{array}$ & $\begin{array}{l}\text { Markers go down with } \\
\text { stress. Albumin buffered by } \\
\text { large extravascular pool and } \\
\text { not sensitive to changes in } \\
\text { acute status; TTHY, TF, } \\
\text { RBP affected by status of } \\
\text { other nutrients. }\end{array}$ \\
\hline Fluid & $\begin{array}{l}\text { Water, beverages, } \\
\text { fruits, and } \\
\text { vegetables }\end{array}$ & $\begin{array}{l}\text { Common indicators: } \\
\text { serum sodium, plasma } \\
\text { osmolality }\left(\mathrm{P}_{\mathrm{osm}}\right) \text {, urine } \\
\text { specific gravity }\left(\mathrm{U}_{\mathrm{sg}}\right) \text {, } \\
\text { urine osmolality }\left(\mathrm{U}_{\mathrm{osm}}\right)\end{array}$ & $\begin{array}{l}\text { Dehydration cut-off: } \\
\mathrm{P}_{\text {osm }}<295 \mathrm{~m}_{\text {osm }} / \mathrm{kg} \\
\mathrm{U}_{\text {sg }}<1.020 \\
\mathrm{U}_{\text {osm }}<700-800 \mathrm{~m}_{\text {osm }} / \mathrm{kg}\end{array}$ & $\begin{array}{l}\text { Decreased urine volume, } \\
\text { dark-yellow urine, } \\
\text { decreased skin turgor, } \\
\text { weak, rapid pulse, elevated } \\
\text { respiratory rate, headache }\end{array}$ & $\begin{array}{l}\text { Limited research supporting } \\
\text { dehydration cutoffs. } P_{\text {osm }} \\
\text { sensitive to small changes } \\
\text { in hydration status and } \\
\text { considered best marker. } U_{\text {sg }} \\
\text { and } U_{\text {osm }} \text { mimic each other } \\
\text { but } U_{\text {sg }} \text { preferred because of } \\
\text { equipment needs, cost, } \\
\text { technical assistance, athlete } \\
\text { compliance, etc. }\end{array}$ \\
\hline Vitamin A & $\begin{array}{l}\text { Egg yolk, milk, } \\
\text { cheese, butter, } \\
\text { fortified } \\
\text { margarine, liver, } \\
\text { orange vegetables, } \\
\text { green vegetables }\end{array}$ & $\begin{array}{l}\text { Most common } \\
\text { measure: plasma } \\
\text { retinol }^{\mathrm{d}}\end{array}$ & $\begin{array}{l}\text { Retinol: } \\
\text { Deficient }<0.7 \mu \mathrm{mol} / \mathrm{L} \\
\text { Severely deficient } \\
<0.35 \mu \mathrm{mol} / \mathrm{L} \\
\text { Excess }>3.5 \mu \mathrm{mol} / \mathrm{L}^{\mathrm{d}} \\
\text { Carotene: } \\
\text { Deficient }<1.5 \mu \mathrm{mol} / \mathrm{L} \\
\text { Excess }>4.65 \mu \mathrm{mol} / \mathrm{L}\end{array}$ & $\begin{array}{l}\text { Early: reduced resistance } \\
\text { to infection, impaired } \\
\text { growth } \\
\text { Late: night blindness } \\
\text { Excess: nausea, fatigue, } \\
\text { headache, skin peeling, } \\
\text { joint pain }\end{array}$ & $\begin{array}{l}\text { Plasma retinol reflective of } \\
\text { vitamin A status only when } \\
\text { liver stores are severely } \\
\text { depleted or when in excess. } \\
\text { RBP can be used as a } \\
\text { surrogate for retinol; it is less } \\
\text { expensive, not temperature } \\
\text { or photosensitive but is } \\
\text { influenced by inflammation } \\
\text { and malnutrition }\end{array}$ \\
\hline Vitamin $\mathrm{C}$ & $\begin{array}{l}\text { Citrus fruit, } \\
\text { melon, berries, } \\
\text { tomatoes, peppers, } \\
\text { broccoli, Brussels } \\
\text { sprouts, cabbage, } \\
\text { cauliflower, } \\
\text { potatoes }\end{array}$ & $\begin{array}{l}\text { Most common } \\
\text { measures: fasting } \\
\text { plasma or serum } \\
\text { ascorbic acid (acute } \\
\text { status) and leukocyte } \\
\text { ascorbic acid (tissue } \\
\text { stores) } \text { e }^{\text {f }}\end{array}$ & $\begin{array}{l}\text { Serum or plasma }{ }^{\mathrm{e}, \mathrm{f}} \\
\text { Deficient }<11.4 \mu \mathrm{mol} / \mathrm{L} \\
\text { Low } 11.4-23 \mu \mathrm{mol} / \mathrm{L} \\
\text { Adequate }>23 \mu \mathrm{mol} / \mathrm{L} \\
\text { Mixed leukocyte } \\
\text { Deficient } \\
<57 \mathrm{nmol} / 10^{8} \text { cells } \\
\text { Low } \\
57-114 \mathrm{nmol} / 10^{8} \text { cells } \\
\text { Adequate } \\
>114 \mathrm{nmol} / 10^{8} \text { cells }\end{array}$ & $\begin{array}{l}\text { Weakness, slow wound } \\
\text { healing, blood vessel } \\
\text { hemorrhages, } \\
\text { perifollicular petechiae } \\
\text { (bleeding/red spots around } \\
\text { hair follicle), bleeding } \\
\text { gums }\end{array}$ & $\begin{array}{l}\text { Vitamin C requirements not } \\
\text { found to be higher in } \\
\text { athletes }{ }^{\mathrm{f}} \text {. Cutoff for } \\
\text { deficiency poorly defined } \\
\text { in general population and } \\
\text { athletes. Women have } \\
\text { higher vitamin C } \\
\text { concentration in tissues } \\
\text { and fluids than men. }\end{array}$ \\
\hline Vitamin D & $\begin{array}{l}\text { Fatty fish, egg } \\
\text { yolk, fortified } \\
\text { milk, juice, } \\
\text { ready-to-eat cereal, } \\
\text { margarine }{ }^{\text {a,g }} \text {, meat } \\
\text { from sun-exposed } \\
\text { agriculture } \\
\text { animals }\end{array}$ & $\begin{array}{l}\text { Valid measure: } \\
\text { Serum } 25(\mathrm{OH}) \mathrm{D}\end{array}$ & $\begin{array}{l}\text { Deficient }<50 \mathrm{nmol} / \mathrm{L} \\
\text { Insufficient }<75 \mathrm{nmol} / \mathrm{L} \\
\text { Sufficient }>75 \mathrm{nmol} / \mathrm{L} \\
\text { Optimal }>40 \mathrm{nmol} / \mathrm{L}^{\mathrm{g}}\end{array}$ & $\begin{array}{l}\text { Unexplained muscle } \\
\text { weakness and pain, joint } \\
\text { pain, undue pain upon } \\
\text { sternum and tibia pressure, } \\
\text { bowing of legs } \\
\text { Excess: hypercalcemia, } \\
\text { fatigue, constipation, } \\
\text { nausea, vomiting, back } \\
\text { pain, headache, } \\
\text { forgetfulness }\end{array}$ & $\begin{array}{l}\text { Cutoffs for insufficiency/ } \\
\text { sufficiency and optimal } \\
\text { somewhat controversial; } \\
\text { more research needed. }\end{array}$ \\
\hline
\end{tabular}


Table 4 (continued)

\begin{tabular}{|c|c|c|c|c|c|}
\hline Nutrient & $\begin{array}{l}\text { Dietary } \\
\text { Sources }^{a}\end{array}$ & $\begin{array}{l}\text { Biochemical Marker } \\
\text { of Status }\end{array}$ & Reference & $\begin{array}{l}\text { Physical } \\
\text { Manifestation }\end{array}$ & $\begin{array}{l}\text { Limitations and } \\
\text { Precautions }\end{array}$ \\
\hline Vitamin E & $\begin{array}{l}\text { Nuts, seeds, } \\
\text { vegetable and } \\
\text { seed oils, } \\
\text { margarine, green, } \\
\text { leafy vegetables }\end{array}$ & $\begin{array}{l}\text { Common measure: } \\
\text { serum alpha- } \\
\text { tocopherol; however, } \\
\text { currently no suitable, } \\
\text { practical marker that } \\
\text { reflects vitamin } \mathrm{E} \\
\text { intake or status }\end{array}$ & $\begin{array}{l}\text { Deficient }<11.6 \mu \mathrm{mol} / \mathrm{L} \\
\text { Adequate } 12-42 \mu \mathrm{mol} / \mathrm{L} \\
\text { Excess }>464 \mu \mathrm{mol} / \mathrm{L}\end{array}$ & $\begin{array}{l}\text { Overt deficiency rare; } \\
\text { subclinical deficiency } \\
\text { difficult to detect. Increase } \\
\text { RBC hemolysis, skeletal } \\
\text { myopathy, neurological } \\
\text { dysfunction (peripheral } \\
\text { neuropathy, } \\
\text { spinocerebellar ataxia) } \\
\text { Excess: headache, fatigue, } \\
\text { diarrhea with megadoses }\end{array}$ & \\
\hline Vitamin K & $\begin{array}{l}\text { K1: green leafy } \\
\text { vegetables, } \\
\text { Brussels sprouts, } \\
\text { cauliflower, } \\
\text { cabbage, other } \\
\text { vegetables }^{\mathrm{a}} \text {; liver, } \\
\text { eggs, fish, meat } \\
\text { (small amounts). } \\
\text { K2: fermented } \\
\text { foods such as } \\
\text { fermented } \\
\text { vegetables, cheese } \\
\text { curds, natto } \\
\text { (fermented } \\
\text { soybeans) }\end{array}$ & $\begin{array}{l}\text { Common measure: } \\
\text { plasma prothrombin } \\
\text { time }\end{array}$ & $\begin{array}{l}\text { Adequate: Plasma } \\
\text { prothrombin time } \\
\text { 10.5-12.5 s } \\
\text { Inadequate: Delayed } \\
\text { clotting time }\end{array}$ & $\begin{array}{l}\text { Overt deficiency rare but } \\
\text { provoked by long-term } \\
\text { antibiotic use. Impaired } \\
\text { blood clotting, easy } \\
\text { bruising, easy bleeding } \\
\text { (e.g., nose bleeds, bleeding } \\
\text { gums, blood in urine/stool, } \\
\text { heavy menstrual bleeding) } \\
\text { Excess: no known toxicity }\end{array}$ & \\
\hline B1 (thiamine) & $\begin{array}{l}\text { All meat } \\
\text { (especially pork), } \\
\text { milk, nuts, whole- } \\
\text { grain and enriched } \\
\text { breads and } \\
\text { cereals, most } \\
\text { vegetables, fruits }\end{array}$ & $\begin{array}{l}\text { Common measure: } \\
\text { erythrocyte } \\
\text { transketolase activity } \\
\text { coefficient, (ETKAC) } \\
\text { (without vs. with added } \\
\text { thiamine) } \text { ) }^{\mathrm{j}, \mathrm{k}} \text {; } \\
\text { thiamine concentration } \\
\text { in urine also common } \\
\text { sensitive measure }\end{array}$ & $\begin{array}{l}\text { ETKAC }^{\mathrm{j}, \mathrm{k}} \\
\text { Normal }=\sim 1.0 \\
\text { Deficient }>1.25 \\
\text { Urinary Thiamine } \\
\text { Poor status } \\
<133 \mathrm{nmol} / \mathrm{d} \\
\text { Low status } \\
133-333 \mathrm{nmol} / \mathrm{d}\end{array}$ & $\begin{array}{l}\text { Poor thiamin status alters } \\
\text { carbohydrate metabolism, } \\
\text { limiting conversion of } \\
\text { pyruvate to acetyl CoA } \\
\text { (pyruvate and lactate } \\
\text { accumulate in blood and } \\
\text { tissues) } \\
\text { Late: Beriberi } \\
\text { (polyneuritis, bradycardia, } \\
\text { peripheral edema, muscle } \\
\text { tenderness, neurological } \\
\text { signs) }\end{array}$ & $\begin{array}{l}\text { ETKAC reflects adequacy of } \\
\text { body stores and is sensitive } \\
\text { to marginal thiamine } \\
\text { deficiency. }{ }^{\mathrm{j}, \mathrm{k}} \text { In individuals } \\
\text { with adequate thiamine } \\
\text { status, urinary } \\
\text { concentrations reflect dietary } \\
\text { intake rather than body } \\
\text { stores. With low stores, the } \\
\text { body conserves thiamine and } \\
\text { urinary concentrations drop. }\end{array}$ \\
\hline $\begin{array}{l}\text { B2 } \\
\text { (riboflavin) }\end{array}$ & $\begin{array}{l}\text { Liver, eggs, milk, } \\
\text { cheese, whole- } \\
\text { grain and enriched } \\
\text { breads and } \\
\text { cereals, green } \\
\text { leafy vegetables }\end{array}$ & $\begin{array}{l}\text { Common measures: } \\
\text { erythrocyte glutathione } \\
\text { reductase activity } \\
\text { coefficient (EGRAC) } \\
\text { (without vs. with added } \\
\text { riboflavin) and urinary } \\
\text { riboflavin excretion } \\
\text { expressed per g } \\
\text { creatinine (Cr); } \\
\text { EGRAC increasingly } \\
\text { used as index of } \\
\text { subclinical deficiency }\end{array}$ & $\begin{array}{l}\text { EGRAC }^{\mathrm{k}} \\
\text { Adequate }<1.2 \\
\text { Low } 1.2-1.4 \\
\text { Deficient }>1.4 \\
\text { Urinary riboflavin g Cr } \\
\text { Low status } \\
50-72 \mathrm{nmol} / \mathrm{g} \mathrm{Cr} \\
\text { Poor status } \\
<50 \mathrm{nmol} / \mathrm{g} \mathrm{Cr}\end{array}$ & $\begin{array}{l}\text { Soreness and burning of } \\
\text { lips, mouth, tongue; } \\
\text { burning and itching eyes, } \\
\text { soars in nasolabial folds }\end{array}$ & $\begin{array}{l}\text { Urinary riboflavin is much } \\
\text { more sensitive to riboflavin } \\
\text { status than serum or plasma } \\
\text { concentrations of riboflavin. }\end{array}$ \\
\hline B3 (niacin) & $\begin{array}{l}\text { All meat, liver, } \\
\text { legumes, peanuts/ } \\
\text { peanut butter, } \\
\text { whole-grain and } \\
\text { enriched breads } \\
\text { and cereals }\end{array}$ & $\begin{array}{l}\text { Common measures } \\
\text { urinary metabolites, } \\
\text { N'-methyl- } \\
\text { nicotinamide (NMN) } \\
\text { and N'-methyl-2- } \\
\text { pyridone-5- } \\
\text { carboxamide (2- } \\
\text { pyridone) })^{\mathrm{j}, \mathrm{k}}\end{array}$ & $\begin{array}{l}\text { Urinary NMN } \mathrm{j,k} \\
\text { Good status } \\
17.5-46.7 \mu \mathrm{mol} / \mathrm{d} \\
\text { Low status } \\
5.8-17.5 \mu \mathrm{mol} / \mathrm{d} \\
\text { Poor status } \\
<5.8 \mu \mathrm{mol} / \mathrm{d}\end{array}$ & $\begin{array}{l}\text { Early: lassitude anorexia, } \\
\text { weakness, depression, } \\
\text { digestive disturbances, } \\
\text { anxiety, and irritability } \\
\text { Later: photosensitivity, } \\
\text { pellagra (diarrhea, } \\
\text { depressive psychosis, } \\
\text { dermatitis skin rash, death) } \\
\text { Excess: flushing, itching, } \\
\text { rash, sweating }\end{array}$ & $\begin{array}{l}\text { A functional test that reflects } \\
\text { body stores not currently } \\
\text { available. NMN reliable for } \\
\text { low intakes but decreases } \\
\text { after signs appear. } \\
\text { 2-pyridone decreases to zero } \\
\text { before clinical signs appear. }\end{array}$ \\
\hline
\end{tabular}


Table 4 (continued)

\begin{tabular}{|c|c|c|c|c|c|}
\hline Nutrient & $\begin{array}{l}\text { Dietary } \\
\text { Sources }^{a}\end{array}$ & $\begin{array}{l}\text { Biochemical Marker } \\
\text { of Status }\end{array}$ & Reference & $\begin{array}{l}\text { Physical } \\
\text { Manifestation }\end{array}$ & $\begin{array}{l}\text { Limitations and } \\
\text { Precautions }\end{array}$ \\
\hline $\begin{array}{l}\text { B6 } \\
\text { (pyridoxine } \\
\text { and related } \\
\text { compounds) }\end{array}$ & $\begin{array}{l}\text { All meat, whole } \\
\text { grains (germ and } \\
\text { aleuronic layer } \\
\text { highest } \\
\text { concentration), } \\
\text { nuts, seeds, } \\
\text { vegetables, some } \\
\text { fruits }\end{array}$ & $\begin{array}{l}\text { Single best indicator: } \\
\text { plasma pyridoxal } \\
\text { 5'-phosphate (PLP), } \\
\text { other relevant markers } \\
\text { include urinary } \\
\text { 4-pyridoxic acid, } \\
\text { erythrocyte aspartate } \\
\text { transaminase activity } \\
\text { coefficient (EASTAC), } \\
\text { and erythrocyte alanine } \\
\text { transaminase activity } \\
\text { coefficient (EALTAC) }\end{array}$ & $\begin{array}{l}\text { PLP } \\
\text { Inadequate Status } \\
<20 \text { to } 30 \mathrm{nmol} / \mathrm{l}^{\mathrm{j}, \mathrm{k}} \\
\text { EASTAC } \\
\text { Good status }<1.60 \\
\text { (but varies by source) } \\
\text { EALTAC } \\
\text { Good status }<1.25 \\
\text { Urinary } 4 \text {-pyridoxic acid } \\
\text { Adequate status } \\
>3.0 \mu \mathrm{mol} / \mathrm{d}\end{array}$ & $\begin{array}{l}\text { Dermatitis, glossitis, } \\
\text { cheilosis (inflammation of } \\
\text { the tongue and lips), } \\
\text { depression, confusion, } \\
\text { oxylate stones, } \\
\text { convulsions; deficiency } \\
\text { rare }^{\mathrm{d}}\end{array}$ & $\begin{array}{l}\text { No single assessment } \\
\text { marker; multiple markers of } \\
\text { status provide best } \\
\text { assessment. }\end{array}$ \\
\hline Biotin & $\begin{array}{l}\text { All meat, liver, } \\
\text { egg yolk, } \\
\text { legumes, nuts, } \\
\text { vegetables }\end{array}$ & $\begin{array}{l}\text { Best measure: urinary } \\
\text { biotin and biotin } \\
\text { metabolites (better } \\
\text { marker than blood } \\
\text { concentrations) }\end{array}$ & $\begin{array}{l}\text { Urinary biotin } \\
\text { Good status } 18-77 \mathrm{nmol} / \mathrm{d} \\
\text { Urinary bisnorbiotin } \\
\text { Good status } 11-39 \mathrm{nmol} / \mathrm{d} \\
\text { Urinary } \\
\text { 3-hydroxyisovaleric acid } \\
\text { Good status } \\
77-195 \mu \mathrm{mol} / \mathrm{d}\end{array}$ & $\begin{array}{l}\text { Rare but could be caused } \\
\text { by excessive intake of raw } \\
\text { egg whites; fatigue, } \\
\text { nausea, and skin rashes }\end{array}$ & $\begin{array}{l}\text { Limited information in } \\
\text { athletes }\end{array}$ \\
\hline $\begin{array}{l}\text { B12 } \\
\text { (cobalamin) }\end{array}$ & $\begin{array}{l}\text { All meat, liver, } \\
\text { milk, eggs, } \\
\text { cheese, nutritional } \\
\text { yeast; not found in } \\
\text { plant foods }\end{array}$ & $\begin{array}{l}\text { Common } \\
\text { measurements }{ }^{\mathrm{k}} \text { : } \\
\text { serum or plasma total } \\
\text { cobalamins, serum } \\
\text { holotranscobalamin II } \\
\text { (cobalamin transport } \\
\text { protein), urinary or } \\
\text { serum methylmalonic } \\
\text { acid (MMA), and } \\
\text { plasma homocysteine }\end{array}$ & $\begin{array}{l}\text { Serum or plasma B12 } \\
\text { Good status } \\
148 \text { to } 185 \mathrm{pmol} / \mathrm{L} \\
\text { Poor status }<148 \mathrm{pmol} / \mathrm{L} \\
\text { Serum MMA } \\
\text { Poor status }>280 \mathrm{nmol} / \mathrm{L} \\
\text { Plasma homocysteine } \\
\text { Poor status }>16 \mu \mathrm{mol} / \mathrm{L} \\
\text { Holotranscobalamin II } \\
\text { Good status } \\
19-50 \text { pmol/L }\end{array}$ & $\begin{array}{l}\text { Early: subtly reduced } \\
\text { cognitive function }{ }^{\mathrm{f}} \\
\text { Late: glossitis, macrocytic } \\
\text { anemia, fatigue, peripheral } \\
\text { neuropathy (numbness, } \\
\text { nerve cell degeneration) }\end{array}$ & $\begin{array}{l}\text { Because there is no "gold } \\
\text { standard", results from two } \\
\text { or more tests should be used } \\
\text { to assess status }{ }^{\mathrm{b}} \text {. Total } \\
\text { cobalamin often lower in } \\
\text { women on oral } \\
\text { contraceptives }{ }^{\mathrm{k}} \text {. MMA } \\
\text { increases when both B12 } \\
\text { status and B6 are low. } \\
\text { Homocysteine increases } \\
\text { when B12 and folate are low. }\end{array}$ \\
\hline Folate & $\begin{array}{l}\text { Green leafy } \\
\text { vegetables, } \\
\text { legumes, most } \\
\text { fruits, enriched } \\
\text { breads and cereals }\end{array}$ & $\begin{array}{l}\text { Recommended } \\
\text { measure: serum or } \\
\text { plasma folate } \\
\text { (indicative of recent } \\
\text { intake), and RBC folate } \\
\text { (indicative of folate } \\
\text { stores and long-term } \\
\text { nutritional status) } \\
\text { plasma homocysteine } \\
\text { also used as functional } \\
\text { biomarker }\end{array}$ & $\begin{array}{l}\text { Poor status } \\
\text { Serum folate }<7 \mathrm{nmol} / \mathrm{L} \\
\text { RBC folate }<305 \mathrm{nmol} / \mathrm{L} \\
\text { Plasma homocysteine } \\
>16 \mu \mathrm{mol} / \mathrm{L}^{0}\end{array}$ & $\begin{array}{l}\text { Early: increased risk for } \\
\text { neural tube defects in } \\
\text { pregnancy } \\
\text { Late: macrocytic anemia, } \\
\text { fatigue, anorexia, angular } \\
\text { cheilosis, glossitis, } \\
\text { insomnia, pallor of skin } \\
\text { and mucous membranes }\end{array}$ & \\
\hline Choline & $\begin{array}{l}\text { Meat, liver, eggs, } \\
\text { peanuts; in most } \\
\text { foods as part of } \\
\text { cell membrane }\end{array}$ & $\begin{array}{l}\text { Common measures: } \\
\text { plasma choline and } \\
\text { phosphatidylcholine }\end{array}$ & $\begin{array}{l}\text { Good status } \\
\text { Plasma choline } 7-20 \mu \mathrm{mol} / \mathrm{L} \\
\text { Plasma phosphatidylcholine } \\
1-1.5 \mathrm{mmol} / \mathrm{L}\end{array}$ & Rare & $\begin{array}{l}\text { Plasma choline not sensitive, } \\
\text { does not drop until severe } \\
\text { deficiency is present. }\end{array}$ \\
\hline $\begin{array}{l}\text { Pantothenic } \\
\text { acid }\end{array}$ & $\begin{array}{l}\text { Liver, all meats, } \\
\text { milk, eggs, } \\
\text { legumes, whole } \\
\text { grains, most } \\
\text { vegetables }\end{array}$ & $\begin{array}{l}\text { Recommended } \\
\text { measure: urinary } \\
\text { pantothenic acid }\end{array}$ & $\begin{array}{l}\text { Urinary pantothenic acid } \\
\text { Good status }>11.8 \mathrm{mmol} / \mathrm{d} \\
\text { and poor status }<5 \mathrm{mmol} / \mathrm{d}^{\mathrm{k}}\end{array}$ & $\begin{array}{l}\text { Rare. Fatigue, anorexia, } \\
\text { nausea, mental depression }\end{array}$ & \\
\hline Calcium & $\begin{array}{l}\text { Milk, yogurt, } \\
\text { cheese, kale, } \\
\text { collard, turnip and } \\
\text { mustard greens, } \\
\text { soy milk, black } \\
\text { strap molasses, } \\
\text { calcium-fortified } \\
\text { juices }\end{array}$ & $\begin{array}{l}\text { Common measure: no } \\
\text { appropriate indicator of } \\
\text { calcium status; } 24-\mathrm{hr} \\
\text { urine somewhat } \\
\text { responsive to changes } \\
\text { in dietary calcium; } \\
\text { calcium in overnight } \\
\text { urine ample indicator of } \\
\text { compliance with }_{\text {calcium supplement }^{\mathrm{n}}}\end{array}$ & - & $\begin{array}{l}\text { Physical manifestations } \\
\text { difficult to detect because } \\
\text { serum calcium is highly } \\
\text { regulated. Chronically low } \\
\text { intake linked to low bone } \\
\text { density, hypertension, } \\
\text { impaired muscle } \\
\text { contraction, muscle } \\
\text { cramps, tetany, } \\
\text { convulsions }\end{array}$ & $\begin{array}{l}\text { Urinary calcium impacted } \\
\text { by other factors (e.g., more } \\
\text { excreted when serum Ca is } \\
\text { high }^{\mathrm{d}} \text { ); also dependent on } \\
\text { dietary sodium, protein, and } \\
\text { phosphorus. Impacted by } \\
\text { vitamin D deficiency. }\end{array}$ \\
\hline
\end{tabular}


Table 4 (continued)

\begin{tabular}{|c|c|c|c|c|c|}
\hline Nutrient & $\begin{array}{l}\text { Dietary } \\
\text { Sources }^{a}\end{array}$ & $\begin{array}{l}\text { Biochemical Marker } \\
\text { of Status }\end{array}$ & Reference & $\begin{array}{l}\text { Physical } \\
\text { Manifestation }\end{array}$ & $\begin{array}{l}\text { Limitations and } \\
\text { Precautions }\end{array}$ \\
\hline Chromium & $\begin{array}{l}\text { Liver and other } \\
\text { organ meats, } \\
\text { oysters, cheese, } \\
\text { whole grains, } \\
\text { beer, asparagus }\end{array}$ & $\begin{array}{l}\text { Best Indicators: } \\
\text { urinary chromium and } \\
\text { plasma chromium } \\
\text { (urinary chromium } \\
\text { represents recent } \\
\text { dietary intake) }^{\mathrm{j}}\end{array}$ & $\begin{array}{l}\text { Urinary chromium } \\
\text { Good status } \\
1.9-38.4 \mathrm{nmol} / \mathrm{d}\end{array}$ & $\begin{array}{l}\text { Impaired glucose } \\
\text { tolerance, purported } \\
\text { disturbances in fat } \\
\text { metabolism, weight loss, } \\
\text { peripheral neuropathy }\end{array}$ & $\begin{array}{l}\text { Urinary chromium is the } \\
\text { better biomarker due to } \\
\text { problems with analytical } \\
\text { method for plasma } \\
\text { chromium }^{\mathrm{j}}\end{array}$ \\
\hline Iodine & $\begin{array}{l}\text { Sea vegetables, } \\
\text { iodized salt; note: } \\
\text { gourmet salts, sea } \\
\text { salt, and processed } \\
\text { foods contain little } \\
\text { to no iodine }\end{array}$ & $\begin{array}{l}\text { Recommended } \\
\text { measure: } 24 \text {-hr urinary } \\
\text { iodine along with } \\
\text { thyroid stimulating } \\
\text { hormone, } \mathrm{T} 3, \mathrm{~T} 4 \text {, and } \\
\text { thyroid autoantibodies }\end{array}$ & $\begin{array}{l}\text { Urinary iodine }^{\mathrm{j}} \\
\text { Mild deficiency } \\
4-8 \mu \mathrm{mol} / \mathrm{d} \\
\text { Moderate deficiency } \\
2-3.9 \mu \mathrm{mol} / \mathrm{d} \\
\text { Severe deficiency } \\
<2 \mu \mathrm{mol} / \mathrm{d}\end{array}$ & $\begin{array}{l}\text { Depressed thyroid gland } \\
\text { activity (chills, weight } \\
\text { gain, fatigue, dry coarse } \\
\text { hair and skin), impaired } \\
\text { growth/development. } \\
\text { Overt: enlarged thyroid } \\
\text { gland (goiter) }\end{array}$ & $\begin{array}{l}\text { 24-hr urine may be } \\
\text { logistically difficult in } \\
\text { athletes. Spot urine reflective } \\
\text { only in populations. }\end{array}$ \\
\hline Iron & $\begin{array}{l}\text { All meats } \\
\text { (especially red } \\
\text { meat, oysters), } \\
\text { legumes, nuts, } \\
\text { seeds, whole- } \\
\text { grains, vegetables, } \\
\text { black strap } \\
\text { molasses, dried } \\
\text { fruit }\end{array}$ & $\begin{array}{l}\text { Several measures } \\
\text { performed } \\
\text { simultaneously provide } \\
\text { best assessment and } \\
\text { determine stage of } \\
\text { deficiency (see } \\
\text { Table 5) } \\
\text { Recommended } \\
\text { measures: serum } \\
\text { ferritin ( } \downarrow \text { stage I), } \\
\text { transferrin saturation, } \\
\text { serum iron transferrin } \\
\text { receptor, zinc } \\
\text { protoporphyrin, } \\
\text { hemoglobin (HGB), } \\
\text { hematocrit, mean } \\
\text { corpuscular volume }\end{array}$ & $\begin{array}{l}\text { Serum ferritin } \\
<15 \mathrm{ng} / \mathrm{mL} \\
\text { Excess }>150 \mathrm{ng} / \mathrm{mL} \\
\text { sTfR }>4.4 \mathrm{mg} / \mathrm{L} \\
\text { Refer to laboratory } \\
\text { specific values for } \\
\text { other iron markers }\end{array}$ & $\begin{array}{l}\text { General: fatigue, } \\
\text { lightheadedness, anorexia, } \\
\text { pale skin and sclera, } \\
\text { elevated heart rate and } \\
\text { respiratory rate, dyspnea. } \\
\text { Overt: anemia, angular } \\
\text { stomatitis, glossitis, } \\
\text { dysphagia, } \\
\text { hypochlorhydria, } \\
\text { koilonychias (spoon } \\
\text { nails) }\end{array}$ & $\begin{array}{l}\text { Presently no consensus on } \\
\text { best markers. Many markers } \\
\text { subject to high biological/ } \\
\text { diurnal variation and } \\
\text { analytical errors. Serum } \\
\text { ferritin often elevated in } \\
\text { endurance athletes. }{ }^{1} \text { Range } \\
\text { of HGB values for } \\
\text { nonanemic athletes overlap } \\
\text { with values for iron } \\
\text { deficiency. Normal HGB } \\
\text { cutoffs higher at altitudes }> \\
1,000 \text { m and } 5-10 \text { g/L lower } \\
\text { in athletes of African } \\
\text { descent. }\end{array}$ \\
\hline Magnesium & $\begin{array}{l}\text { Nuts, seeds, whole } \\
\text { grains, legumes, } \\
\text { milk and yogurt, } \\
\text { most vegetables } \\
\text { (including green } \\
\text { leafy-vegetables) }\end{array}$ & $\begin{array}{l}\text { Frequent measures: } \\
\text { serum magnesium; } \\
\text { other tests include: } \\
\text { RBC magnesium, } \\
\text { ionized magnesium in } \\
\text { serum and RBC, } \\
\text { urinary magnesium } \\
\text { with or without oral } \\
\text { magnesium load }\end{array}$ & $\begin{array}{l}\text { Good status } \mathrm{s}^{\mathrm{j}} \\
\text { Urinary magnesium } \\
3-5 \mathrm{mmol} / \mathrm{d} \\
\text { Serum magnesium } \\
0.74-1.07 \mathrm{mmol} / \mathrm{L}\end{array}$ & $\begin{array}{l}\text { Muscle weakness, muscle } \\
\text { spasm, confusion, loss of } \\
\text { appetite; other } \\
\text { neuromuscular, } \\
\text { gastrointestinal, and } \\
\text { personality changes } \\
\text { (apathy, depression, } \\
\text { nervousness, delirium, } \\
\text { hallucinations, } \\
\text { psychosis) }{ }^{\text {d; }} \text { suboptimal } \\
\text { status common. Overt } \\
\text { deficiency rare. } \\
\text { Excess: diarrhea }\end{array}$ & $\begin{array}{l}\text { No single available test } \\
\text { accurately assesses } \\
\text { magnesium status. Serum } \\
\text { magnesium concentration } \\
\text { has low sensitivity and } \\
\text { specificity. Tests for } \\
\text { biomarkers are cumbersome } \\
\text { and not routinely used in } \\
\text { clinical setting. }\end{array}$ \\
\hline Phosphorus & $\begin{array}{l}\text { All protein } \\
\text { products (meat, } \\
\text { milk, eggs, } \\
\text { legumes, whole } \\
\text { grains), soft } \\
\text { drinks, some } \\
\text { processed foods }\end{array}$ & $\begin{array}{l}\text { Common measure: } \\
\text { serum phosphorus } \\
\text { concentration }\end{array}$ & $\begin{array}{l}\text { Reference range: } \\
\text { Serum phosphorous } \\
0.87-1.45 \mathrm{mmol} / \mathrm{L}^{\mathrm{J}}\end{array}$ & $\begin{array}{l}\text { Dietary deficiency rare; } \\
\text { excess possible with } \\
\text { supplementation, laxative } \\
\text { abuse. Increased urinary } \\
\text { excretion of calcium, } \\
\text { magnesium and potassium, } \\
\text { bone pain, muscle } \\
\text { weakness, impaired } \\
\text { growth, low oxygen } \\
\text { delivery. } \\
\text { Excess: impaired calcium } \\
\text { regulation }\end{array}$ & $\begin{array}{l}\text { Serum phosphorus has low } \\
\text { sensitivity and specificity. }\end{array}$ \\
\hline Potassium & $\begin{array}{l}\text { Most vegetables } \\
\text { and fruits }\end{array}$ & $\begin{array}{l}\text { Common measure: } \\
\text { potassium in 24-hr } \\
\text { urine reflective of } \\
\text { dietary intake; } \\
\text { potassium in second } \\
\text { void morning urine also } \\
\text { correlates with intake }^{\mathrm{d}}\end{array}$ & $\begin{array}{l}\text { Reference range: } \\
25-125 \mathrm{mmol} / \mathrm{d}^{\mathrm{j}}\end{array}$ & $\begin{array}{l}\text { Possible elevated risk for } \\
\text { hypertension, cardiac } \\
\text { arrhythmias, muscle } \\
\text { weakness, respiratory } \\
\text { failure, ileus } \\
\text { Excess: cardiac } \\
\text { arrhythmias }\end{array}$ & \\
\hline
\end{tabular}


Table 4 (continued)

\begin{tabular}{|c|c|c|c|c|c|}
\hline Nutrient & $\begin{array}{l}\text { Dietary } \\
\text { Sources }^{a}\end{array}$ & $\begin{array}{l}\text { Biochemical Marker } \\
\text { of Status }\end{array}$ & Reference & $\begin{array}{l}\text { Physical } \\
\text { Manifestation }\end{array}$ & $\begin{array}{l}\text { Limitations and } \\
\text { Precautions }\end{array}$ \\
\hline Selenium & $\begin{array}{l}\text { Meat, seafood, } \\
\text { cereals and grains, } \\
\text { dairy, and fruits } \\
\text { and vegetables }\end{array}$ & $\begin{array}{l}\text { Common measure: } \\
\text { serum selenium }\end{array}$ & $\begin{array}{l}\text { Reference range: } \\
0.58-1.82 \mu \mathrm{mol} / \mathrm{L}\end{array}$ & $\begin{array}{l}\text { Deficiency: whitening of } \\
\text { nail beds, muscle pain and } \\
\text { weakness, loss of pigment } \\
\text { of hair and nails; Keshan } \\
\text { disease (endemic } \\
\text { cardiomyopathy); Kashin- } \\
\text { Beck disease (endemic } \\
\text { osteoarthritis) } \\
\text { Excess: nail and hair loss, } \\
\text { skin lesions, polyneuritis }\end{array}$ & $\begin{array}{l}\text { Low sensitivity; reference } \\
\text { ranges not well established. } \\
\text { Selenium status highly } \\
\text { depending on selenium } \\
\text { concentration of soil where } \\
\text { animal was raised or food } \\
\text { was grown. }\end{array}$ \\
\hline Sodium & $\begin{array}{l}\text { Processed foods, } \\
\text { salt }\end{array}$ & $\begin{array}{l}\text { Common measure: } \\
\text { sodium in 24-hr urine } \\
\text { reflective of dietary } \\
\text { intake; sodium in } \\
\text { second void morning } \\
\text { urine also correlates } \\
\text { with intake }^{\mathrm{d}}\end{array}$ & $\begin{array}{l}\text { Reference range: } \\
40-220 \mathrm{mmol} / \mathrm{d}^{\mathrm{J}}\end{array}$ & $\begin{array}{l}\text { Hyponatremia, volume } \\
\text { depletion, light } \\
\text { headedness, cerebral } \\
\text { edema. Deficiency very } \\
\text { rare but could occur with } \\
\text { excessive sweating and } \\
\text { extremely low dietary } \\
\text { intake. } \\
\text { Excess: increased risk for } \\
\text { hypertension }\end{array}$ & \\
\hline Zinc & $\begin{array}{l}\text { All meats, } \\
\text { shellfish } \\
\text { (especially } \\
\text { oysters), dairy } \\
\text { products, nuts, } \\
\text { seeds, whole- } \\
\text { grains, legumes, } \\
\text { vegetables }\end{array}$ & $\begin{array}{l}\text { No available markers } \\
\text { provide reliable } \\
\text { indicators of zinc status } \\
\text { Common measures: } \\
\text { serum zinc } \\
\text { concentration as well as } \\
\text { urine and hair } \\
\text { concentrations }\end{array}$ & $\begin{array}{l}\text { Good status }^{\mathrm{J}} \\
\text { Serum zinc } \\
10.7-18.4 \mu \mathrm{mol} / \mathrm{L} \\
\text { Urine } \\
2.3-18.4 \mu \mathrm{mol} / \mathrm{d} \\
\text { Poor status } \\
\text { Serum zinc } \\
<10.7 \mu \mathrm{mol} / \mathrm{L}\end{array}$ & $\begin{array}{l}\text { Marginal: delayed physical } \\
\text { growth, poor appetite, } \\
\text { hypogeusia, impaired } \\
\text { immune function, poor } \\
\text { wound healing, } \\
\text { hypogonadism } \\
\text { Excess: impaired } \\
\text { immunity, low HDL, } \\
\text { impaired copper } \\
\text { metabolism }\end{array}$ & $\begin{array}{l}\text { Serum zinc maintained at the } \\
\text { expense of tissue zinc (i.e., } \\
\text { a late indicator of zinc pool } \\
\text { depletion), is not influenced } \\
\text { by dietary zinc and } \\
\text { decreased with stress, } \\
\text { infection, and inflammation } \\
\text { and increased with fasting } \\
\text { serum zinc also altered by } \\
\text { exericise. }\end{array}$ \\
\hline
\end{tabular}

Sources: ${ }^{\mathrm{a} O t t e n}$ et al., 2006; ${ }^{\mathrm{b}}$ White et al., 2012; ${ }^{\mathrm{c}}$ Oppliger et al., 2005; ${ }^{\mathrm{d}}$ Gibson, 2005; ${ }^{\mathrm{e}}$ U.S. Centers for Disease Control and Prevention, 1998); ${ }^{\mathrm{f}} \mathrm{Peake}, 2003 ;{ }^{\mathrm{g}}$ Larson-Meyer \& Willis, 2010; ${ }^{\mathrm{h}}$ Alexander et al., 2017; ${ }^{\mathrm{i}}$ Linus Pauling Institute Micronutrient Information Center, 2000-2017; ${ }^{\mathrm{j}}$ Fischbach \& Dunning, 2015; ${ }^{\mathrm{k}}$ Food and Nutrition Board of the Institute of Medicine, $1998 ;{ }^{1}$ Deacon \& Peel, 2015; ${ }^{\mathrm{m}}$ Manore et al., 1993; ${ }^{\mathrm{n}}$ Lee \& Nieman, 2013; ${ }^{\circ}$ Selhub et al., 2000.

Table 5 Biochemical Markers of Iron Deficiency

\begin{tabular}{lll}
\hline Stage & General Description & $\begin{array}{l}\text { Biochemical Marker and Direction } \\
\text { of Change ( } \uparrow \text { or } \downarrow \text { ) With Deficiency* }\end{array}$ \\
\hline I: Iron depletion & Progressive reduction in hepatic iron storage & $\downarrow$ Ferritin \\
II: Iron-deficient erythropoiesis & Iron stores exhausted; iron supply to RBC progressively & $\downarrow$ Ferritin \\
& reduced & $\downarrow$ Transferrin saturation \\
& & $\downarrow$ Serum iron \\
& & $\uparrow$ Soluble transferrin receptor \\
& & $\downarrow$ ZnPP concentration \\
III: Iron-deficiency anemia & Complete exhaustion of iron stores, declining circulating & $\downarrow$ Ferritin \\
& iron, frank microcytic, hypochromic anemia & $\downarrow$ HCT \\
& & $\downarrow$ MCV
\end{tabular}

Abbreviations: $\mathrm{ZnPP}=$ zinc protoporphyrin; $\mathrm{HGB}=$ hemoglobin; $\mathrm{HCT}=$ hematocrit; $\mathrm{MCV}=$ mean corpuscular.

* Refers to clinic/laboratory specific reference ranges. Combined Sources: Gibson, 2005; Lee \& Nieman, 2013; U.S. Centers for Disease Control and Prevention, 1998; Zoller \& Vogel, 2004.

acute or chronic exercise, and many may be increased by hemoconcentration from dehydration or reduced by hemodilution when there is an increase in plasma volume associated with endurance training or heat acclimatization. For example, ferritin is an acute state reactant and may be artificially raised in response to a strenuous exercise session (Deakin \& Peeling, 2015), whereas zinc may be preferentially stored in muscle after exercise training, thereby lowering serum concentrations (Manore et al., 1993).
Therefore, care is needed to standardize the conditions of collection of biological samples and to interpret the results in the light of these effects.

In undertaking biochemical tests, a cost:benefit analysis should consider the practicality of sample collection and the potential errors involved with sample collection, preparation, storage, and methodological analysis (Gibson, 2005). Care must be taken to complete collection of the appropriate sample within the constraints 
of the athlete's training and performance schedule (e.g., fasting blood, collection timing in relation to training or time of day, or random vs. 24-hr urine collection), avoid sample contamination (especially for trace minerals), prevent hemolysis of erythrocytes in whole blood, serum, or plasma before processing, and prohibit nutrient breakdown/ metabolism before analysis. Some biochemical tests may also be altered by exercise and/or circadian variation and best collected at the same time of day when the athlete is well rested and often fasted. Additionally, correct laboratory protocols (sample collection chemicals, centrifuge speed, storage temperature, and analytical technique) will minimize errors that may make a laboratory value unusable as a single or serial measure. In interpreting results, both cut-off points (values associated with clinical or functional manifestations of deficiency) and reference ranges (values derived from a sample of healthy individuals) are used. Unfortunately, cut-off- points are not available for all nutrients (Table 4). Furthermore, both reference sources are often age-, sex-, race-, and laboratory-dependent and reliant on precision of analytical procedure. As mentioned earlier, nonspecificity as well as poor sensitivity are limitations to many biochemical tests. For example, a test, such as mean cell volume (MCV), may suggest presence of compromised nutritional status yet lack the specificity to pinpoint the deficient nutrient and/or determine whether the underlying cause is nutritional or pathophysiological. A biomarker such as serum retinol or zinc concentration may not decline until overt deficiency is present, lacking sensitivity as an early nutrition marker. Biochemical markers are therefore best assessed along with the other nutrition assessment methods.

\section{C: Clinical}

The clinical assessment of nutritional status involves collection of a detailed history, a physical examination, and the interpretation of signs and symptoms that may be related to compromised nutrition status or excess nutrient intake (Gibson, 2005; Lee \& Nieman, 2013). The history should address the athlete's recent and past history, family history, and medication and supplement use. The nutrition-focused physical exam can be done by the sports dietitian or alternately/additionally obtained from the physician's exam. A systems approach is recommended to ensure efficiency and thoroughness (Demarest Litchford, 2017), with the eyes, mouth, lips, tongue, scalp hair, neck, hands, fingernails, skin, muscles, and joints being assessed for signs of nutrient deficiency (see Table 6) (Academy of Nutrition and Dietetics, 2015). The exam should be individually tailored and guided by information collected in the diet and biochemical assessments (Demarest Litchford, 2017). Information on general well-being, appetite, chewing, swallowing, taste sensation, gastrointestinal health (i.e., nausea, vomiting, diarrhea, constipation, bowel frequency and regularity, stool consistency), sleep patterns, and perceived metabolic/physiological improvement in response to training should also be collected. In female athletes, information on the menstrual cycle and menstrual bleeding patterns should not be overlooked.

Typically, the physical exam is likely to be unremarkable; overt deficiencies are rare in the healthy athlete, and subclinical deficiencies are difficult to detect from examination alone. Exceptions include the presence of iron deficiency, disordered eating, or long-term consumption of nutrient-poor fad diets. Many clinical signs and symptoms are also general and nonspecific (i.e., fatigue, weakness, anorexia), and could result from non-nutritional factors or compromised status of any number of nutrients (Table 6). Moreover, single nutrient deficiencies are rare; more common are the clustering of nutrient deficiencies depending on food intake patterns. For example, compromised status of folate, vitamin $\mathrm{C}$, and potassium may be present in an athlete who rarely consumes fruit or vegetables whereas low status of the B vitamins and iron could be observed in an athlete following a low-carbohydrate, vegetarian diet.

Collection of detailed information on current medication and dietary supplement (vitamins, minerals, herbal and sport supplement) use, including the timing and duration of intake, and possible food-drug interactions is also essential (Deal \& VanReken, 2017) even in the healthy athlete. Food-drug interactions encompass interactions between and among prescriptions or over-the-counter medications and specific foods, nutrients, or supplements. These interactions can in general change the effect of the drug, alter its side effects, induce toxicity, alter nutrient absorption or metabolism (Deal \& VanReken, 2017), or impact supplement tolerance and effectiveness. The elite athlete may be taking medication for an acute illness or chronic condition, which could interact with specific foods or supplements consumed. For example, an athlete may be taking tetracycline for acne, theophylline for asthma, ethinylestradiol as part of an oral contraceptive preparation, or a corticosteroid for an acute or chronic injury. An athlete may self-prescribe Tagamet for heartburn, Allegra for an allergy, or take Tamiflu for "the flu". Each of these medications, and a long list of others, has the potential to alter nutritional status, or be impacted by dietary factors including sports supplements. Table 7 summarizes common food-drug interactions, including potential interactions with dietary supplements, and highlights the importance of checking for such interactions using reputable sources (Ernst, 1999; Natural Medicines, 2017; U.S. National Library of Medicine, 2017).

\section{E: Environment}

The collection of data on environmental, social, and lifestyle factors that potentially influence nutritional status, as well as supplement interest and use, may be undertaken within the dietary assessment or clinical history but are highlighted as a separate component in the A-E model. Specific data include information on the athlete's socioeconomic status, living arrangements, grocery shopping and cooking abilities, transportation, training regimen, education, culture, psycho-social support system, religious practices, and personal belief system. It is essential to assess whether the athlete is under financial constraints, has responsibility for grocery shopping and/or menu planning, has the time and basic skills to prepare simple or complex meals, follows cultural or religious practices that dictates fasting or restricting certain foods or supplements, or has personal beliefs that dictates food choice. Specific examples of cultural, religious, or personal beliefs include not eating meat and dairy in the same meal (Jewish Orthodox), not eating pork (Jewish Orthodox, Hindu, Buddhist), avoiding caffeine (Muslims, Mormons, and Seventh Day Adventists), following plant-based diets (Buddhists, Hindu, Seventh Day Adventists, vegans, vegetarians, animal rights activists), eating in moderation (Buddhists, Muslims) (Yadrick, 2017) and eating mostly local foods (environmentalist, locavore). These beliefs can also impact interest in dietary supplements or the desire to understand the ingredients and sources used in supplement formulations.

In addition, the environmental component encompasses the desire/ability to change and barriers to change (Boosalis, 2010), which may be assessed most readily using the transtheoretical model of health behavior change (Table 8) (Zimmerman et al., 2000). This assessment may be particularly useful in the sports setting because an athlete not yet considering the benefits of diet on performance and health will require a different effort to another 
Table 6 Clinical Indicators of Nutrient Deficiencies Important for the Nutrition-Focused Physical Exam

\begin{tabular}{|c|c|c|c|}
\hline Body System & Expected Outcome & Signs of Malnutrition & $\begin{array}{l}\text { Other Possible Non-nutritional } \\
\text { Causes }\end{array}$ \\
\hline Scalp hair & Shiny, firm in scalp & $\begin{array}{l}\text { Easily pluckable (PEM), sparse hair (protein, biotin, zinc), } \\
\text { transverse depigmentation of hair (cyclic PEM, rare), } \\
\text { corkscrew hairs (copper, vitamin C), dry, coarse, receding } \\
\text { hairline (iodine) }\end{array}$ & $\begin{array}{l}\text { Excess bleaching, coloring; } \\
\text { chemotherapy or radiation therapy }\end{array}$ \\
\hline Eyes & $\begin{array}{l}\text { Bright, clear conjunctive } \\
\text { covering white sclera, eyes } \\
\text { adjust easily to light }\end{array}$ & $\begin{array}{l}\text { Pallor (pale color) of conjunctiva (iron); spots, dryness, } \\
\text { night blindness (vitamin A) }\end{array}$ & Allergies, non-nutritional anemia \\
\hline Lips & Smooth, pinkish & $\begin{array}{l}\text { Dry, cracked or with sores in corners (e.g., angular } \\
\text { cheilosis) (B vitamins) }\end{array}$ & $\begin{array}{l}\text { Sunburn, windburn, lip licking, } \\
\text { excessive salivation }\end{array}$ \\
\hline Mouth & $\begin{array}{l}\text { Pinkish-red tongue } \\
\text { (without swelling), sense } \\
\text { of taste, gums without } \\
\text { bleeding, swelling or pain, } \\
\text { teeth with normal enamel } \\
\text { and without spotting }\end{array}$ & $\begin{array}{l}\text { Glossitis, general (folate, B6), scarlet, raw or "beefy" } \\
\text { tongue (riboflavin, niacin, B6, folate, vitamin B12); slick } \\
\text { tongue/atrophic lingual papillae (riboflavin, niacin, folate, } \\
\text { vitamin B12), protein, iron, lack of taste (zinc), bleeding, } \\
\text { retracted gums (vitamin C), white spots or mottling of } \\
\text { teeth (excess fluoride) }\end{array}$ & $\begin{array}{l}\text { Certain medication side effects, poor } \\
\text { dental hygiene, periodontal disease }\end{array}$ \\
\hline Neck & $\begin{array}{l}\text { No enlargements of parotid } \\
\text { or thyroid glands }\end{array}$ & $\begin{array}{l}\text { Thyroid nodule or enlarged thyroid (iodine, selenium), } \\
\text { enlarged parotid (PEM, bulimia) }\end{array}$ & $\begin{array}{l}\text { Goiter from non-nutritional cause; } \\
\text { mumps, stones, tumors }\end{array}$ \\
\hline Nails & $\begin{array}{l}\text { Smooth, firm, pinkish- } \\
\text { color }\end{array}$ & $\begin{array}{l}\text { Pallor of nail beds, spoon-shaped nails (iron, possibly } \\
\text { B12, folate), transverse ridging (PEM) }\end{array}$ & $\begin{array}{l}\text { Exposure of nails to damaging } \\
\text { chemicals }\end{array}$ \\
\hline Skin & Smooth, firm, good color & $\begin{array}{l}\text { Reduced skin turgor (dehydration, inadequate fluid } \\
\text { intake), dry rough, (iodine) with lack of fat under skin } \\
\text { (essential fatty acids, PEM, B vitamins), scaling (essential } \\
\text { fatty acids, vitamin A, zinc), pigmentation, desquamation } \\
\text { of sun-exposed areas (niacin), skin rash (niacin, B6), } \\
\text { dermatitis, general (B vitamins), follicular hyperkeratosis } \\
\text { (vitamins A and C), perifollicular petechiae (vitamin C), } \\
\text { easy bruising/purpura (vitamin C and K), cellophane } \\
\text { appearance (PEM), poor healing of cuts and wounds } \\
\text { (PEM, vitamin C, zinc), skin peeling (excess vitamin A) }\end{array}$ & $\begin{array}{l}\text { Non-nutritional dermatitis or skin } \\
\text { rash, poor skin care, diabetes } \\
\text { mellitus, medication side effects, } \\
\text { aging }\end{array}$ \\
\hline Bones and joints & Normal anatomy & $\begin{array}{l}\text { Unexplained joint pain, bending of ribs, epiphyseal } \\
\text { swelling, bow legs (vitamin D) }\end{array}$ & \\
\hline Neuromuscular & $\begin{array}{l}\text { Normal musculature with } \\
\text { no pain or neuromuscular } \\
\text { dysfunction }\end{array}$ & $\begin{array}{l}\text { Unexplained muscle pain (vitamin D), unexplained } \\
\text { weakness (PEM, magnesium, phosphorus, vitamin D), } \\
\text { undue pain with sternal or tibial pressure (vitamin D), } \\
\text { muscle cramping, tetany (magnesium, calcium), } \\
\text { myopathy (vitamin E), peripheral neuropathy (e.g., } \\
\text { weakness, paresthesia, ataxia), decreased tendon reflexes, } \\
\text { fine tactile, vibratory and position sense (thiamine, B12, } \\
\text { excess or insufficient pyridoxine, vitamin E), } \\
\text { spinocerebellar ataxia (vitamin E) }\end{array}$ & Injury, neuromuscular disorders \\
\hline Neurological & Normal & $\begin{array}{l}\text { Headache (vitamin A excess, dehydration), dementia } \\
\text { (niacin, vitamin B12), peripheral, vibratory sense and } \\
\text { position sense (thiamine, B12, excess or insufficient } \\
\text { pyridoxine, vitamin E); general neurological dysfunction } \\
\text { (vitamin E) }\end{array}$ & $\begin{array}{l}\text { Non-nutritional neurological } \\
\text { conditions, aging }\end{array}$ \\
\hline
\end{tabular}

Note. Table outlines common signs and symptoms of malnutrition. Unless otherwise specified, nutrient(s) provided in parenthesis is most probably cause of marginal intake/ nutrient deficiency. PEM = protein energy malnutrition.

Compiled sources: Gibson, 2005; Lee \& Nieman, 2013; Otten et al., 2006; U.S. Centers for Disease Control and Prevention, 1998.

who desires dietary change but needs strategies to do so. An athlete's stage of change may be determined by careful listening (particularly concerning the athlete's reasoning for seeing the dietitian) or by providing the athlete with a "readiness to change ruler" (Zimmerman et al., 2000) or formal questionnaire (Pekmezi et al., 2010). To our knowledge, however, tools specific to sports nutrition have not yet been developed. Overall, this information helps the sports dietitian recognize that the purpose of a single encounter is not to get the athlete to change behavior but to identify their stage of change and engage the athlete in the process of moving to the next stage (Clement, 2008; Pekmezi et al., 2010; Zimmerman et al., 2000), whether that be eating more fruit, timing dietary intake to exercise, or incorporating dietary supplementation.

\section{Conclusion}

Nutritional assessment is an important first step in advising athletes on dietary strategies that include dietary supplementation, and in evaluating the effectiveness of such approaches. Dietary assessment is the cornerstone of this, but should be performed 
Table 7 Common Food-Drug Interactions of Potential Concern in Some Athletes

\begin{tabular}{|c|c|c|}
\hline Interaction & Expected Consequence & Advice for Athlete \\
\hline \multicolumn{3}{|l|}{ General Dietary Factors } \\
\hline $\begin{array}{l}\text { Alcohol and specific drugs metabolized by } \\
\text { liver cytochrome P- } 450 \text { system }\end{array}$ & $\begin{array}{l}\text { Decreased ability to break down drug; can } \uparrow \\
\text { risk of toxicity. May also } \uparrow \text { risk of irritation/ } \\
\text { damage to GI tract. }\end{array}$ & $\begin{array}{l}\text { Avoid alcohol while taking certain } \\
\text { supplements and medications }\end{array}$ \\
\hline Black pepper and Allegra (antihistamine) & Piperine in pepper $\uparrow$ s potency of medication & $\begin{array}{l}\text { Avoid heavy spicing with black pepper while } \\
\text { on antihistamine }\end{array}$ \\
\hline $\begin{array}{l}\text { Coffee (caffeine) and certain thyroid (and } \\
\text { other) medications (levothyroxine) }\end{array}$ & Coffee $\downarrow$ s absorption of medication & $\begin{array}{l}\text { Consume medication and coffee several hours } \\
\text { apart }\end{array}$ \\
\hline Fad diets (such as alkaline ash diet) and drugs & Drugs that are weak acids or bases are resorbed & Discuss with physician \\
\hline
\end{tabular}

that are weak acids or bases

Low-carbohydrate, high-protein diet and theophylline (antiasthmatic)

Grapefruit and seville oranges (in marmalade) and specific drugs of all categories and some herbal supplements that are metabolized by a specific intestinal cytochrome P-450 enzyme (CYP4A4)

Tea and theophylline (antiasthmatic)

\section{Nutrient-Specific Factors}

Calcium and antibiotics including tetracycline and ciprofloxacin

Calcium, iron, zinc, folic acid, and vitamin B12 and gastric acid secretion inhibitors

(e.g., H2 blockers, proton pump inhibitors, Tagamet)

Calcium, magnesium, potassium along with sodium and diuretics

Folate and oral contraceptives

Fat soluble vitamins, folate, and vitamin B12 and cholestyramine (antilipidemic)

Fiber and tricyclic antidepressants or certain antibiotics

Sodium and lithium (antimanic)

Tyramine-containing foods (e.g., aged cheeses, cured meats, fermented vegetables) and monoamine oxidase inhibitors (antidepressants, some anti-infectants) and Yohimbe (performance enhancer)

Vitamin B6 and certain tuberculosis drugs

Vitamin D and specific drugs (e.g., anticonvulsants, corticosteroids, Tagamet, theophylline, thiazide diuretics, and certain statins) in renal tubule in the nonionic state; a change in urinary $\mathrm{pH}$ by extreme diets may alter the amount of drug in the nonionic state that may $\uparrow$ or $\downarrow$ drug resorption and alter drug toxicity and effectiveness, respectively

Increased liver metabolism of drug which decreases effectiveness

Furanocoumarin in grapefruit/Seville oranges inhibits activity of CYP4A4 that metabolizes the drug; this $\uparrow$ s drug availability and risk of drug toxicity

Tea $\uparrow s$ action of drug

Chelation reaction between mineral and medication reduces absorption of mineral and drug Reduced $\mathrm{pH}$ in gut alters cleavage from dietary sources

Different classes of diuretics alter renal absorption of these minerals and can lead to increased losses of calcium, magnesium, or potassium

Oral contraceptives impair folate metabolism (mildly) and decrease markers of folate and B12 status

Drug $\downarrow$ s absorption of vitamins A, D, E, K, and most likely folate and B12

Interaction of fiber and drug in intestines $\downarrow$ s drug absorption

Lithium is tied to sodium resorption in renal tubules. High sodium intake $\uparrow s$ lithium excretion and drug effectiveness. Dehydration or low sodium intake $\uparrow s$ lithium resorption and potential for drug toxicity.

Drug and herb prevent breakdown of tyramine which is a vasoactive amine. Can result in severe elevations of blood pressure (hypertensive crisis).

Drug blocks conversion (activation) of pyridoxine to pyridoxal 5-phosphate (important for protein metabolism)

Anticonvulsants, corticosteroids, Tagamet, and theophylline result in decreased vitamin D status whereas thiazide diuretics, Atorvastatin, and Rosuvastatin increase vitamin D
Discuss with physician

Discuss with pharmacist or physician

Avoid grapefruit completely (effects of a single glass of juice can last $>72 \mathrm{hr}$ )

Consume medication and teas several hours apart

Take $>2$ hr apart

Consider MVI, alter timing of medication with meals

Increase dietary intake or consider MVI

Ensure adequate folate intake; consider MVI

MVI recommended

Consume medication and fiber-containing foods several hours apart

Diet with consistent sodium intake; avoid dehydration

Avoid foods containing tyramine

\section{Monitor status}

Monitor status 
Table 7 (continued)

\begin{tabular}{|c|c|c|}
\hline Interaction & Expected Consequence & Advice for Athlete \\
\hline \multicolumn{3}{|l|}{ Herbal Supplements and Ergogenic Aids } \\
\hline $\begin{array}{l}\text { Creatine and drugs that are potential } \\
\text { nephrotoxins including the broad spectrum } \\
\text { antibiotics ampicillin, gentamycin, } \\
\text { cyclosporine, and tobramycin and nonsteroidal } \\
\text { anti-inflammatory drugs including ibuprofen, } \\
\text { indomethacin, and numerous others }\end{array}$ & $\begin{array}{l}\text { Because creatine might adversely affect renal } \\
\text { function there is some concern (not yet shown) } \\
\text { that combining creatine with potentially } \\
\text { nephrotoxic drugs might have additive harmful } \\
\text { effects on kidney function. }\end{array}$ & $\begin{array}{l}\text { Monitor use of creatine when taking } \\
\text { potentially nephrotoxic drugs. }\end{array}$ \\
\hline $\begin{array}{l}\text { Caffeine and bitter orange (and other herbals } \\
\text { that may raise blood pressure) }\end{array}$ & $\begin{array}{l}\text { Caffeine in combination with bitter orange can } \\
\text { raise blood pressure and heart rate in otherwise } \\
\text { healthy, normotensive individuals. The effect is } \\
\text { thought to increase risk of adverse } \\
\text { cardiovascular events. }\end{array}$ & Avoid use of these herbs with caffeine. \\
\hline Caffeine and both echinacea and kudzu & $\begin{array}{l}\text { Echinacea ( } 400 \text { mg daily for } 8 \text { days) and kudzu } \\
\text { (amount not specified) seems to inhibit the oral } \\
\text { clearance of caffeine; effect thought to be due to } \\
\text { the inhibition of cytochrome P450 1A2 } \\
\text { (CYP1A2) enzyme, which is involved in } \\
\text { caffeine metabolism. }\end{array}$ & Avoid use of these herbs with caffeine. \\
\hline $\begin{array}{l}\text { Echinacea, labrador tea, goldenseal, chai hu } \\
\text { and Tamiflu }\end{array}$ & Herbs have potential to $\downarrow$ potency of Tamiflu. & Avoid use of herbs when taking Tamiflu. \\
\hline Ginger and ginseng and specific medications & $\begin{array}{l}\text { Herbs have potential to raise blood pressure and } \\
\text { may alter toxicity of drugs that have similar side } \\
\text { effects. }\end{array}$ & Discontinue herbal supplementation. \\
\hline $\begin{array}{l}\text { Resveratrol (large quantities) and many } \\
\text { medications }\end{array}$ & $\begin{array}{l}\text { Supplementation with resveratrol enhances } \\
\text { potency of some drugs. }\end{array}$ & Check for interactions with certain drugs. \\
\hline $\begin{array}{l}\text { Whey Protein and tetracycline and quinolone } \\
\text { antibiotics }\end{array}$ & $\begin{array}{l}\text { Theoretically, use of whey protein with certain } \\
\text { antibodies might decrease drug and calcium } \\
\text { absorption. Whey protein contains minerals } \\
\text { that might bind antibodies in the gut. }\end{array}$ & $\begin{array}{l}\text { Consume whey protein and these antibiotics } \\
\text { several hours apart. }\end{array}$ \\
\hline
\end{tabular}

Compiled sources: Deal \& VanReken, 2017; Natural Medicines, 2017; Shojania, 1982.

Table 8 Overview of Stages of Change and Appropriate Education Strategies for Each Stage

\begin{tabular}{|c|c|c|}
\hline Stage & Brief Description & Strategy \\
\hline Precontemplation & $\begin{array}{l}\text { Athlete not even considering change or in denial; does not } \\
\text { believe issue applies to him/her; believes consequences are } \\
\text { not important or serious }\end{array}$ & $\begin{array}{l}\text { Educate on risks versus benefits and positive outcomes } \\
\text { related to change }\end{array}$ \\
\hline Contemplation & $\begin{array}{l}\text { Athlete ambivalent about change; athlete weighs costs versus } \\
\text { benefits of change and barriers to change (time, extra work, } \\
\text { giving up favorite foods, etc.) }\end{array}$ & $\begin{array}{l}\text { Help athlete identify barriers and support systems and } \\
\text { address concerns and misconceptions }\end{array}$ \\
\hline Preparation & Athlete prepares to experiment with small changes & $\begin{array}{l}\text { Work with athlete to develop realistic goals and timeline for } \\
\text { change, provide positive reinforcement }\end{array}$ \\
\hline Action & Athlete takes definitive action to change & Provide positive reinforcement and specific ideas/strategies \\
\hline $\begin{array}{l}\text { Maintenance and } \\
\text { relapse prevention }\end{array}$ & Athlete strives to maintain new behavior over time & $\begin{array}{l}\text { Provide encouragement and support and specific ideas/ } \\
\text { strategies as needed }\end{array}$ \\
\hline
\end{tabular}

Compiled sources: Peeters \& Claessens, 2009; Zimmerman et al., 2000.

within the context of a complete evaluation of anthropometric, biochemical, clinical, and environmental components. Collection of dietary intake data can be challenging with the potential for significant error of validity and reliability at all stages, including the dietary recall and food recording by athletes, coding of data by dietitians, estimation of nutrient composition using nutrient food tables and dietary software programs, and expression of data relative to reference standards (i.e., eating guidance systems and DRIs). However, there are also limitations in the methodologies used to complete anthropometric assessment and biochemical analysis, as not all nutrients have practical and reliable markers of nutritional status, and few have reference norms for the well-trained athlete. Establishment of such reference norms for well-trained athletes should be a future research priority. An assessment of clinical signs, environmental factors, and potential food-drug interactions can complete the task. Overall, the assessment process can help the athlete understand that supplement intake cannot reverse poor food choices and an inadequate diet, while a well-chosen diet can ensure maximal benefit from supplementation.

\section{Acknowledgments}

Manuscript preparation was undertaken primarily by DELM with expert assistance and editing of LB and KW. 


\section{References}

Academy of Nutrition and Dietetics. (2015). Nutrition Terminology Reference Manuel (eNCPT): Dietetics Language for Nutrition Care. Retrieved from http://ncpt.webauthor.com

Ackland, T.R., Lohman, T.G., Sundgot-Borgen, J., Maughan, R.J., Meyer, N.L., Stewart, A.D., \& Muller, W. (2012). Current status of body composition assessment in sport: Review and position statement on behalf of the ad hoc research working group on body composition health and performance, under the auspices of the I.O.C. Medical Commission. Sports Medicine, 42(3), 227-249. PubMed doi:10. 2165/11597140-000000000-00000

Adelman, M.O., Dwyer, J.T., Woods, M., Bohn, E., \& Otradovec, C.L. (1983). Computerized dietary analysis systems: A comparative view. Journal of the American Dietetic Association, 83(4), 421-429. PubMed

Alexander, B.M., Ingold, B.C., Fensterseifer, S., Austin, K.J., Hollis, B., Wechler, P., \& Larson-Meyer, D.E. (2017). Sun exposure in pigs increases the vitamin D nutritional quality of pork. PLoS ONE, 12(11), e0187877. doi:10.1371/journal.pone.0187877

Ballor, D.L. (1996). Exercise training and body composition changes. In A.F. Roche, S.B. Heymsfield, \& T.G. Lohman (Eds.), Human body composition (pp. 287-304). Champaign, IL: Human Kinetics.

Basiotis, P.P., Welsh, S.O., Cronin, F.J., Kelsay, J.L., \& Mertz, W. (1987). Number of days of food intake records required to estimate individual and group nutrient intakes with defined confidence. The Journal of Nutrition, 117(9), 1638-1641. PubMed doi:10.1093/jn/117.9.1638

Bentzur, K.M., Kravitz, L., \& Lockner, D.W. (2008). Evaluation of the BOD POD for estimating percent body fat in collegiate track and field female athletes: A comparison of four methods. Journal of Strength and Conditioning Research, 22(6), 1985-1991. PubMed doi:10. 1519/JSC.0b013e318185f196

Bingham, S.A. (1991). Limitations of the various methods for collecting dietary intake data. Annals of Nutrition \& Metabolism, 35(3), 117-127. PubMed doi:10.1159/000177635

Boosalis, M.G. (2010). ABCDEs of sports nutrition assessment. Paper presented at the 26th Annual SCAN Symposium, San Diego, CA.

Braakhuis, A.J., Hopkins, W.G., Lowe, T.E., \& Rush, E.C. (2011). Development and validation of a food-frequency questionnaire to assess short-term antioxidant intake in athletes. International Journal of Sport Nutrition and Exercise Metabolism, 21(2), 105-112. PubMed doi:10.1123/ijsnem.21.2.105

Braakhuis, A.J., Meredith, K., Cox, G.R., Hopkins, W.G., \& Burke, L.M. (2003). Variability in estimation of self-reported dietary intake data from elite athletes resulting from coding by different sports dietitians. International Journal of Sport Nutrition and Exercise Metabolism, 13(2), 152-165. PubMed doi:10.1123/ijsnem.13.2.152

Burke, L.M. (2015). Dietary assessment methods for the athlete: Pros and Cons of different methods. Sports Science Exchange, 28(150), 1-6.

Burke, L.M., Hawley, J.A., Wong, S.H., \& Jeukendrup, A.E. (2011). Carbohydrates for training and competition. Journal of Sports Sciences, 29(Suppl. 1), S17-S27. doi:10.1080/02640414.2011. 585473

Clark, R.R., Bartok, C., Sullivan, J.C., \& Schoeller, D.A. (2004). Minimum weight prediction methods cross-validated by the fourcomponent model. Medicine \& Science in Sports \& Exercise, 36(4), 639-647. PubMed doi:10.1249/01.MSS.0000121942.84630.6C

Clement, D. (2008). The transtheoretical model: An exploratory look at its applicability to injury rehabilitation. Journal of Sport Rehabilitation, 17(3), 269-282. doi:10.1123/jsr.17.3.269

Conway, J.M., Ingwersen, L.A., \& Moshfegh, A.J. (2004). Accuracy of dietary recall using the USDA five-step multiple-pass method in men:
An observational validation study. Journal of the American Dietetic Association, 104(4), 595-603. PubMed doi:10.1016/j.jada.2004. 01.007

Conway, J.M., Ingwersen, L.A., Vinyard, B.T., \& Moshfegh, A.J. (2003). Effectiveness of the US Department of Agriculture 5-step multiplepass method in assessing food intake in obese and nonobese women. The American Journal of Clinical Nutrition, 77(5), 1171-1178. PubMed doi:10.1093/ajen/77.5.1171

Deakin, V., \& Peeling, P. (2015). Iron. In L.M. Burke \& V. Deakin (Eds.), Clinical sports nutrition (5th ed.). Sydney, Australia: McGraw-Hill.

Deal, L.L., \& VanReken, D.W. (2017). Clinical: Food-drug interactions. In L.K. Mahn \& J.L. Raymond (Eds.), Krause's food and the nutrition care process (13th ed., pp. 122-138). Saint Louis, MO: Elsevier.

Demarest Litchford, M. (2017). Clinical: Biochemical, physical and functional assessments. In L.K. Mahn \& J.L. Raymond (Eds.), Krause's food and the nutrition care process (13th ed., pp. 98-121). Saint Louis, MO: Elsevier.

Driskell, J.A., \& Wolinsky, I. (Eds.). (2010). Nutritional assessment of athletes (2nd ed.). CRC Press.

Ernst, E. (1999). The Complete German Commission E monographs. Focus on Alternative and Complementary Therapies, 4(4), 225. doi:10.1111/j.2042-7166.1999.tb01157.x

Fischbach, F., \& Dunning, M. (2015). A manual of laboratory and diagnostic tests (9th ed.). Philadelphia, PA: Wolters Kluwer Health/Lippincott Williams \& Wilkins.

Fogelholm, M., \& Lahti-Koski, M. (1991). The validity of a food use questionnaire in assessing the nutrient intake of physically active young men. European Journal of Clinical Nutrition, 45(5), 267-272. PubMed

Food and Nutrition Board. (2000). Dietary reference intakes: Application in dietary assessment. Washington, DC: National Academy Press.

Food and Nutrition Board of the Institute of Medicine. (1998). Dietary reference intakes: Thiamin, riboflavin, niacin, vitamin $B-6$, folate, vitamin B-12, pantothenic acid, biotin, and choline. Washington, DC: National Academy Press.

Freedman, L.S., Commins, J.M., Moler, J.E., Arab, L., Baer, D.J., Kipnis, V., ... Willett, W. (2014). Pooled results from 5 validation studies of dietary self-report instruments using recovery biomarkers for energy and protein intake. American Journal of Epidemiology, 180(2), 172-188. PubMed doi:10.1093/aje/kwu116

Gibson, R.S. (2005). Principles of nutritional assessment (2nd ed.). New York, NY: Oxford University Press.

Guilland, J.C., Aubert, R., Lhuissier, M., Peres, G., Montagnon, B., Fuchs, F., ... Astorg, P.O. (1993). Computerized analysis of food records role of coding and food composition database. European Journal of Clinical Nutrition, 47(6), 445-453. PubMed

Halliday, T.M., Peterson, N.J., Thomas, J.J., Kleppinger, K., Hollis, B.W., \& Larson-Meyer, D.E. (2011). Vitamin D status relative to diet, lifestyle, injury, and illness in college athletes. Medicine \& Science in Sports \& Exercise, 43(2), 335-343. PubMed doi:10.1249/MSS. 0b013e3181eb9d4d

Johansson, G., Akesson, A., Berglund, M., Nermell, B., \& Vahter, M. (1998). Validation with biological markers for food intake of a dietary assessment method used by Swedish women with three different dietary preferences. Public Health Nutrition, 1(3), 199-206. PubMed doi:10.1079/PHN19980031

Keats, S., \& Wiggins, S. (2014). Future diets. Implications for agriculture and food prices. Retrieved from https://www.odi.org/future-diets

Kopinski, S., Engel, T., Cassel, M., Frohlich, K., Mayer, F., \& Carlsohn, A. (2015). Ultrasound applied to subcutaneous fat tissue measurements in international elite canoeists. Intertional Journal of Sports Medicine, 36(14), 1134-1141. doi:10.1055/s-0035-1555857 
Larson-Meyer, D.E., \& Willis, K.S. (2010). Vitamin D and athletes. Current Sports Medicine Reports, 9(4), 220-226. PubMed doi:10. 1249/JSR.0b013e3181e7dd45

Lee, R.D., \& Nieman, D.C. (2013). Nutritional assessment (6th ed.). New York, NY: McGraw Hill.

Linus Pauling Institute Micronutrient Information Center. (2000-2017). Vitamin K. Retrieved from http://lpi.oregonstate.edu/mic/vitamins/ vitamin-K

Livingstone, M.B., \& Black, A.E. (2003). Markers of the validity of reported energy intake. The Journal of Nutrition, 133(Suppl. 3), 895S-920S. doi:10.1093/jn/133.3.895S

Lohman, T.G. (1988). Anthropometry and body composition. Champaign, IL: Human Kinetics.

Lohman, T.G., Harris, M., Teixeira, P.J., \& Weiss, L. (2000). Assessing body composition and changes in body composition. Another look at dual-energy X-ray absorptiometry. Annals of the New York Academy of Sciences, 904, 45-54. PubMed doi:10.1111/j.1749-6632.2000. tb06420.x

Magkos, F., \& Yannakoulia, M. (2003). Methodology of dietary assessment in athletes: Concepts and pitfalls. Current Opinion in Clinical Nutrition and Metabolic Care, 6(5), 539-549. PubMed doi:10.1097/ 00075197-200309000-00007

Manore, M.M., Helleksen, J.M., Merkel, J., \& Skinner, J.S. (1993). Longitudinal changes in zinc status in untrained men: Effects of two different 12-week exercise training programs and zinc supplementation. Journal of the American Dietetic Association, 93(10), 1165-1168. PubMed doi:10.1016/0002-8223(93)91653-8

Maughan, R.J., \& Shirreffs, S.M. (2011). IOC Consensus Conference on Nutrition in Sport, 25-27 October 2010, International Olympic Committee, Lausanne, Switzerland. Journal of Sports Sciences, 29(Suppl. 1), S1. doi:10.1080/02640414.2011.619339

Meyer, N.L., Sundgot-Borgen, J., Lohman, T.G., Ackland, T.R., Stewart, A.D., Maughan, R.J., ... Muller, W. (2013). Body composition for health and performance: A survey of body composition assessment practice carried out by the Ad Hoc Research Working Group on Body Composition, Health and Performance under the auspices of the IOC Medical Commission. British Journal of Sports Medicine, 47(16), 1044-1053. PubMed doi:10.1136/bjsports-2013-092561

Moon, J.R., Tobkin, S.E., Costa, P.B., Smalls, M., Mieding, W.K., O'Kroy, J.A., ... Stout, J.R. (2008). Validity of the BOD POD for assessing body composition in athletic high school boys. Journal of Strength and Conditioning Research, 22(1), 263-268. PubMed doi:10.1519/JSC.0b013e31815f60ce

Muller, W., Horn, M., Furhapter-Rieger, A., Kainz, P., Kropfl, J.M., Maughan, R.J., \& Ahammer, H. (2013). Body composition in sport: A comparison of a novel ultrasound imaging technique to measure subcutaneous fat tissue compared with skinfold measurement. British Journal of Sports Medicine, 47(16), 1028-1035. doi:10.1136/ bjsports-2013-092232

Muller, W., Lohman, T.G., Stewart, A.D., Maughan, R.J., Meyer, N.L., Sardinha, L.B., ... Ackland, T.R. (2016). Subcutaneous fat patterning in athletes: Selection of appropriate sites and standardisation of a novel ultrasound measurement technique: Ad hoc working group on body composition, health and performance, under the auspices of the IOC Medical Commission. British Journal of Sports Medicine, 50(1), 45-54. PubMed doi:10.1136/bjsports-2015-095641

Nana, A., Slater, G.J., Hopkins, W.G., \& Burke, L.M. (2012a). Effects of daily activities on dual-energy X-ray absorptiometry measurements of body composition in active people. Medicine \& Science in Sports \& Exercise, 44(1), 180-189. doi:10.1249/MSS.0b013e318228b60e

Nana, A., Slater, G.J., Hopkins, W.G., \& Burke, L.M. (2012b). Techniques for undertaking dual-energy X-ray absorptiometry whole-body scans to estimate body composition in tall and/or broad subjects. International Journal of Sport Nutrition and Exercise Metabolism, 22(5), 313-322. doi:10.1123/ijsnem.22.5.313

Nana, A., Slater, G.J., Hopkins, W.G., \& Burke, L.M. (2013). Effects of exercise sessions on DXA measurements of body composition in active people. Medicine \& Science in Sports \& Exercise, 45(1), 178-185. doi:10.1249/MSS.0b013e31826c9cfd

Nana, A., Slater, G.J., Hopkins, W.G., Halson, S.L., Martin, D.T., West, N.P., \& Burke, L.M. (2016). Importance of standardized DXA protocol for assessing physique changes in athletes. International Journal of Sport Nutrition and Exercise Metabolism, 26(3), 259-267. PubMed doi:10.1123/ijsnem.2013-0111

Natural Medicines. (2017). Food, herbs \& supplements database. Stockton, CA: Natural Medicines. Retrieved from naturalmedicines. therapeuticresearch.com

Oppliger, R.A., Magnes, S.A., Popowski, L.A., \& Gisolfi, C.V. (2005). Accuracy of urine specific gravity and osmolality as indicators of hydration status. International Journal of Sport Nutrition and Exercise Metabolism, 15(3), 236-251. PubMed doi:10.1123/ijsnem. 15.3.236

Otten, J.J., Hellwig, J.P., \& Meyers, L.D. (2006). The dietary reference intakes: The essential guide to nutrient requirements. Washington, DC: Food and Nutrition Board, Institutes of Medicine.

Peake, J.M. (2003). Vitamin C: Effects of exercise and requirements with training. International Journal of Sport Nutrition and Exercise Metabolism, 13(2), 125-151. PubMed doi:10.1123/ijsnem.13.2.125

Peeters, M.W., \& Claessens, A.L. (2009). Effect of deviating clothing schemes on the accuracy of body composition measurements by air displacement plethysmography. International Journal of Body Composition Research, 7(4), 123-129.

Peeters, M.W., \& Claessens, A.L. (2011). Effect of different swim caps on the assessment of body volume and percentage body fat by air displacement plethysmography. Journal of Sports Sciences, 29(2), 191-196. doi:10.1080/02640414.2010.530677

Pekmezi, D., Barbera, B., \& Marcus, B.H. (2010). Using the transtheoretical model to promote physical activity. Acsms Health \& Fitness Journal, 14(4), 8-13. doi:10.1249/FIT.0b013e3181e37e11

Phillips, S.M., \& Van Loon, L.J. (2011). Dietary protein for athletes: From requirements to optimum adaptation. Journal of Sports Sciences, 29(Suppl. 1), S29-S38. doi:10.1080/02640414.2011.619204

Popa, A.D., Botnariu, G.E., \& Antohe, I. (2017). Self-reported anthropometrics: An adequate evaluation? EC Nutrition, 7(6), 252-260.

Poslusna, K., Ruprich, J., de Vries, J.H., Jakubikova, M., \& van’t Veer, P. (2009). Misreporting of energy and micronutrient intake estimated by food records and 24 hour recalls, control and adjustment methods in practice. The British Journal of Nutrition, 101(Suppl. 2), S73-S85. doi:10.1017/S0007114509990602

Rodriguez-Sanchez, N., \& Galloway, S.D. (2015). Errors in dual energy $\mathrm{X}$-ray absorptiometry estimation of body composition induced by hypohydration. International Journal of Sport Nutrition and Exercise Metabolism, 25(1), 60-68. PubMed doi:10.1123/ijsnem.2014-0067

Selhub, J., Jacques, P.F., Bostom, A.G., Wilson, P.W., \& Rosenberg, I.H. (2000). Relationship between plasma homocysteine and vitamin status in the Framingham study population. Impact of folic acid fortification. Public Health Reviews, 28(1-4), 117-145.

Shojania, A.M. (1982). Oral contraceptives: Effect of folate and vitamin B12 metabolism. Canadian Medical Association Journal, 126(3), 244-247. PubMed

Sinning, W.E., Dolny, D.G., Little, K.D., Cunningham, L.N., Racaniello, A., Siconolfi, S.F., \& Sholes, J.L. (1985). Validity of "generalized" equations for body composition analysis in male athletes. Medicine \& Science in Sports \& Exercise, 17(1), 124-130. PubMed 
Sinning, W.E., \& Wilson, J.R. (1984). Validity of generalized equations for body-composition analysis in women athletes. Research Quarterly for Exercise and Sport, 55(2), 153-160. doi:10.1080/02701367. 1984.10608392

Stewart, A., Marfell-Jones, M., Olds, T., \& de Ridder, H. (2011). International standards for anthropometric assessment. Lower Hutt, New Zealand: The International Society for the Advancement of Kinanthropometry.

Thomas, D.T., Erdman, K.A., \& Burke, L.M. (2016). American College of Sports Medicine Joint Position Statement. Nutrition and Athletic Performance. Medicine \& Science in Sports \& Exercise, 48(3), 543-568. PubMed doi:10.1249/MSS.0000000000000852

Thompson, F.E., \& Subar, A.F. (2008). Dietary assessment methodology. In A.M. Coulston \& C.J. Boushey (Eds.), Nutrition in the prevention and treament of disease (2nd ed., pp. 3-39). San Diego, CA: Academic Press.

Trabulsi, J., \& Schoeller, D.A. (2001). Evaluation of dietary assessment instruments against doubly labeled water, a biomarker of habitual energy intake. American Journal of Physiology-Endocrinology and Metabolism, 281(5), E891-E899. PubMed doi:10.1152/ajpendo. 2001.281.5.E891

U.S. Centers for Disease Control and Prevention. (1998). Recommendations to prevent and control iron deficiency in the United States. Morbidity and Mortality Weekly Report, 47(RR-3), 1-36. Retrieved from https://www.cdc.gov/mmwr/pdf/rr/rr4703.pdf

U.S. Department of Agriculture (USDA) Agricultural Research Service. (2017). USDA national nutrient database for standard reference. Retrieved from www.mal.usda.gov/fnic/foodcomp/search

U.S. Department of Health and Human Services and U.S. Department of Agriculture. (2015, December). 2015-2020 dietary guidelines for Americans. 8th Edition. Retrieved from http://health.gov/ dietaryguidelines/2015/guidelines/

U.S. National Library of Medicine (Producer). (2017, January 23). MedlinePlus Drugs \& Supplements. Retrieved from http://www. nlm.nih.gov/medlineplus/druginformation.html

Wagner, D.R., Cain, D.L., \& Clark, N.W. (2016). Validity and reliability of a-mode ultrasound for body composition assessment of NCAA
Division I athletes. PLoS ONE, 11(4), e0153146. PubMed doi:10. 1371/journal.pone.0153146

Wagner, D.R., \& Heyward, V.H. (1999). Techniques of body composition assessment: A review of laboratory and field methods. Research Quarterly for Exercise and Sport, 70(2), 135-149. PubMed doi:10. 1080/02701367.1999.10608031

Wagner, D.R., \& Heyward, V.H. (2004). Applied body composition assessment (2nd ed.). Champaign, IL: Human Kinetics.

Weaver, C.M. (1990). Assessing calcium status and metabolism. The Journal of Nutrition, 120(Suppl. 11), 1470-1473. doi:10.1093/jn/120. suppl_11.1470

White, J.V., Guenter, P., Jensen, G., Malone, A., Schofield, M., ... A.S.P.E.N. Malnutrition Task Force; A.S.P.E.N. Board of Directors. (2012). Consensus statement: Academy of Nutrition and Dietetics and American Society for Parenteral and Enteral Nutrition: Characteristics recommended for the identification and documentation of adult malnutrition (undernutrition). JPEN. Journal of Parenteral and Enteral Nutrition, 36(3), 275-283. PubMed doi:10.1177/ 0148607112440285

Wojciak, R.W., Krejpcio, Z., Czlapka-Matyasik, M., \& Jeszka, J. (2004). Comparison of the hair bioelements in vegeterian and non-vegeterian women. Trace Elements and Electrolytes, 21(3), 141-144. doi:10. 5414/TEP21141

Wunderlich, S.M., Feldman, C., Kane, S., \& Hazhin, T. (2008). Nutritional quality of organic, conventional, and seasonally grown broccoli using vitamin $\mathrm{C}$ as a marker. International Journal of Food Sciences and Nutrition, 59(1), 34-45. PubMed doi:10.1080/09637480701453637

Yadrick, M.M. (2017). Food and nutrient delivery: Diet guidelines, nutrient standards and cultural competency. In L.K. Mahn \& J.L. Raymond (Eds.), Krause's food and the nutrition care process (13th ed., pp. 173-190). Saint Louis, MO: Elsevier.

Zimmerman, G.L., Olsen, C.G., \& Bosworth, M.F. (2000). A 'stages of change' approach to helping patients change behavior. American Family Physician, 61(5), 1409-1416. PubMed

Zoller, H., \& Vogel, W. (2004). Iron supplementation in athletes-first do no harm. Nutrition, 20(7-8), 615-619. doi:10.1016/j.nut.2004. 04.006 